\title{
SUDĖTINIAI PRIJUNGIAMIEJI LAIKO SAKINIAI ŠIAURĖS ŽEMAIČIŲ TARMĖJE (REMIANTIS XX A. II PUSÉS PAVELDU)
}

\author{
Jūratė PAJĖDIENĖ \\ Lietuvių kalbos institutas
}

\section{Ivadas}

Straipsniu tęsiamas šiaurès žemaičių tarmès respondentams būdingo sudètinių prijungiamųjų laiko sakinių vartojimo modelių tyrimas ${ }^{1}$. Šị kartą pristatomas viename iš XX a. antrosios pusès šiaurès žemaičių kretingiškių ${ }^{2}$ kalbèjimo paveldą įamžinusiu leksikografijos šaltiniu - Šiaurès vakaru žemaičiu žodynas. Ylakiu, Lenkimu, Mosèdžio, Skuodo, Šačiu apylinkiu šnektos $A-O, P-\check{Z}$ (žr. Vanagienè, 2014; 2015, toliau - ŠVŽŽ 1, 2) 3 - randamų prijungiamųjų laiko sakinių struktūrinių ir semantinių modelių aprašas. Dẻl tiriamos medžiagos gausumo straipsnyje aptariami tik pirmajame šio žodyno tome užfiksuoti laiko sakiniai. Jų rasta 1431. Aprašant ŠVŽŽ 1 laiko sakinius palyginimui pasitelkiama anksčiau atlikta kitos žemaičiu patarmès - šiaurès žemaičiu telšiškių - kalbẻjimo tekstų sąvaduose Taip šneka tirkšliškiai (toliau - TŠT) ir Šiaurès žemaičiai telšiškiai (toliau - ŠŽT) aptiktų laiko sakinių struktūros ir morfosintaksinių modelių analizè (žr. Pajẻdienė 2018). Abiem atvejais medžiaga duomenų bazei atrinkta ir analizuota remiantis tomis pačiomis teorinėmis nuostatomis. Jas trumpai galima pristatyti taip:

- Šalutinis sakinys laikomas prijungiamuoju, kai jis yra kito sakinio dalimi ${ }^{4}$. Praleidus prijungiamąij dèmeni pagrindinio dèmens gramatiné struktūra nėra suardoma, nes šalutinis dėmuo tik modifikuoja pagrindinio sakinio tarinị (plg. Hengeveld 1998: 335).

Autore dèkoja abiem ịslaptintiems Recenzentams už pastabas ir pasiūlymus.

2 Apie šiaurès žemaičių (arba vadinamųjų dounininku) kalbos ypatybes bei šiaurès žemaičių telšiškių ir kretingiškių patarmių skirtumą, paremtą $u, i / /$, $e$ kaita negalūniniuose skiemenyse žr. Zinkevičius 1994: 85-87; 112-120; 114; Pabrèža 2013; 2017: 47-48.

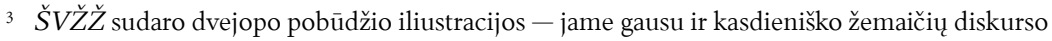
(1960-1990 m. Birutė Vanagienè nuolat užrašinėdavo savo artimiausios aplinkos pašnekesius), ir 1989-1996 m. vykusių dialektologinių ekspedicijų metu užfiksuotų pokalbių medžiagos (plg. Subačius 2014, XII; XIV-XVII).

4 Šalutinis sakinys apibūdinamas pagal santykị su stipresne konstrukcija, kurios dalimi jis yra (plg. Huddleston 1999: 339) arba apibūdinamas kaip tai, kas nèra pagrindinis sakinys (plg. Langacker 1991: 436). Dèl asimetrinio santykio prijungiamieji sakiniai paprastai yra suvokiami ne kaip argumentai, bet tik kaip informacijos apie propoziciją (pagrindinį sudètinio sakinio dèmenį) priedas (plg. Whaley 1997: 250). 
- Šalutinio sakinio dèmens struktūrai būdingas jungiamasis žodis (arba prijungimo rodiklis). Pasak Bernd’o Kortmann'o, prieveiksminių sakinių prijungimo rodiklis (adverbial subordinator) - tai nelinksniuojama žodžio forma, galinti paveikti ${ }^{5}$ visą prijungiamąji dèmenį, bet pati jame neatliekanti konkretaus sintaksinio (t. y. sakinio dalies, pvz. laiko aplinkybès) vaidmens ${ }^{6}$; šalutinio demens struktūroje prijungimo rodiklis paprastai užima kraštinę poziciją (plg. Kortmann 1997: 72-73; 1998: 458-460).

- Prieveiksminiai laiko sakiniai lokalizuoja pasakojimo situacijas laike ir tai yra tik dalis santykinès laiko reikšmès, atsiskleidžiančios lyginant vieno veiksmo santykị su kitu (plg. Huddleston, Pullum, ed. 2002: 695-696). Laiko sakiniais kartu su veiksmų vienalaikiškumo ar sekos reikšmėmis gali būti perteikiami ir kiti hiponimiški bendrai laiko sąvokai parametrai: momentas, trukmé, pasikartojimas (plg. van der Auwera 1999: 11). Tokiu parametrų perteikimą lemia tam tikra pagrindinio ir šalutinio sakinio tarinių atitiktis - jų gramatinio laiko formų savitarpio santykis, veiksmažodžiu veikslo reikšmių derẻimas su jungiamojo žodžio semantika bei kitos sakinio sandaros ypatybès. Vienos gramatinès išraiškos modelis gali turèti dvejopą reikšmę: nurodyti ne vien tik tam tikros tvarkos veiksmų lokalizaciją laiko skalejje (plg. Levinson 2003: 16), bet ir priežastinę jų sąsają.

- Prijungiamųju laiko sakinių pozicija pagrindinio dèmens atžvilgiu dabartinejje lietuvių kalboje apibūdinama kaip laisva, nes reikšmių santyki lemia ne šalutinio dèmens pozicija, bet jungiamojo žodžio vaidmuo ir darna su abiejų sudètinio sakinio dėmenų veiksmažodžio formomis (veikslo ir gramatinio laiko atžvilgiu) (plg. Ambrazas 1976b: 844-846; 2006: 680; Holvoet 2003: 107). Vis dèlto kalbos vienetu pateikimo tvarka atspindi informacijos reikšmingumą diskurse, todèl ir prijungiamojo sakinio dèmenų išdèstymas paryškina norimus dèmesio sutelkimo centrus. Šnekamojoje kalboje dèmesio sutelkimo momentai gali išnirti ir netikètai - spontaniškai prisiminus būtinybę pateikti laiko nuorodą. Kai kurie sakinių sudarymo modeliai yra kur kas dažnesni už kitus, todèl didesnès

5 Dar apie jungiamojo žodžio (connective) funkcines galimybes, nežiūrint ịprastinio morfosintaksinio vaidmens, žr. Nau, Ostrowski 2010: 7-8.

6 Kortmann'o vykdytame Europos kalbų prieveiksminių sakinių tyrime buvo laikomasi prijungimo rodiklių natūralumo kriterijaus kilmès (kad nebūtų archaizmas) ir kalbos standartiškumo (kad nebūtų dialektizmas) atžvilgiu (plg. Kortmann 1997: 72-73). Tiriant šnekamosios kalbos atmainą reprezentuojančius tarminius tekstus nuostata, kad prijungimo rodiklis neturi priklausyti žymètų žodžių registrui, gali būti laikoma atitikimu įprastumo kriterijui. Dar plg. Kortmann (1997: 357). 
apimties skirtingų šaltinių teikiamų duomenų sugretinimas leidžia pamatyti populiariausių struktūrinių modelių parinktis, o ypatingesnès sandaros atvejais - ir dèl sustabarèjimo išsilaikiusių sintaksinių struktūrų gyvybingumą, naujoviškų sakinio potipių su iš bendrinès kalbos perimtu prijungimo rodikliu prisijaukinimo pradžią ar tarmei tradiciškai būdingų, bet iki šiol dar nepastebėtų (neaptartų) variantų atvejus.

Remiantis prijungimo rodikliu kaip sintaksinio aprašo atskaitos pagrindu straipsnyje pateikiama kiekybinė ir struktūrinė laiko sakinių, aptinkamų $\grave{S} V Z ̌ Z ̌ ~ 1$, analizè, daugiausia dèmesio skiriant laiko sakinių potipių dažnumo santykiui, pozicinių modelių pasiskirstymui ir tariniais einančių veiksmažodžių formų derèjimui tarpusavyje. Laiko sakiniai aprašomi funkcinius prijungimo rodiklių reikšmių tipus skiriant ị dvi grupes: 1) bendrosios ir momentinès laiko reikšmès ${ }^{7}$ bei 2) laiko ribos.

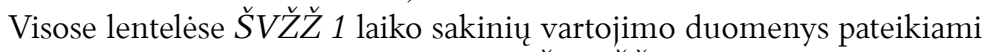
sugretinti su analogišku aspektu įvertintais $T S ̌ T$ ir $\check{S} Z ̌ T$ laiko sakiniais. Sakinių pavyzdžiai pateikiami kartojant šaltinyje užrašytą transkripciją (žr. Vanagienė 2014, XXVIII), bet aiškinamajame tekste vartojamos į bendrinę kalbą atstatytos žemaitiškų jungiamųiu ar atliepiamųiu žodžių formos ${ }^{8}$.

\section{2. Šiaurès žemaičių kretingiškių prijungiamieji laiko sakiniai (remiantis ŠVŽŽ 1 iliustracine medžiaga)}

Didžiąją ŠVŽŽ 1 prijungiamųjų laiko sakinių dali sudaro sakiniai su bendrosios ir/ ar momentinès laiko reikšmès jungiamaisiais žodžiais (91,4\%); laiko ribos prijungimo rodiklius turinčiu sakinių vartosena retesnè $(\sim 8,6 \%)$ (beveik identišku santykiu laiko sakiniai pasiskirsto ir $T S ̌ T-$ plg. 1 lentelëje pateiktus duomenis) $)^{9}$.

7 Dviejų potipių sakinius su šiais sąlygiškai įvardintais prijungimo rodikliais aptarti kartu yra patogu dèl bendrosios reikšmès prijungimo rodiklių vartojimo ir veiksmų vienalaikiškumą, ir seką nusakančiuose sakiniuose.

8 Jos atitinka Lietuviu kalbos žodyno (LKŽe) transponavimo variantus, plg.: kaip (<- kãp), tuo $(<-t o ̣)$; kai kuriais atvejais transponuotoji ir tarminè formos fonetiškai sutampa, plg.: kumet (=kumet), tumet (=tumet).

9 XVI-XVII a. senuosiuose lietuvių raštuose matomas kiek kitoks šių dviejų laiko sakinių potipių vartojimo dažnumo santykis: Jono Bretkūno, Mikalojaus Daukšos ir Konstantino Sirvydo pamokslų rinkiniuose laiko ribos sakiniai vidutiniškai sudaro $\sim 18 \%$ (atitinkamai: $22,5 \% ; 17,8 \%$ ir $15,8 \%$ ), o laiko sakiniai su bendrosios reikšmès ir momentinès reikšmès jungiamaisiais žodžiais — 82\% (atitinkamai 77,5\%, 82,2\% ir 84,2\%); šiuose didelès apimties šaltiniuose santykinis laiko ribos sakinių vartojimo dažnumas labai panašus (vidutiniškai $\sim 5$ vnt. autoriniame lanke), o sakinių su bendrosios reikšmès žodžiais - kiek skiriasi (nuo 18 iki 27 vnt.) (plg. Pajëdienè 2012: 9; 39; 40). 
1 lentele

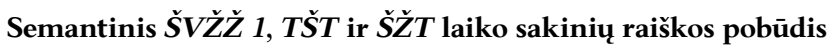

\begin{tabular}{|c|c|c|c|}
\hline \multirow[t]{2}{*}{ Laiko sakiniai } & \multirow{2}{*}{$\begin{array}{c}\begin{array}{c}\text { Šiaurès žemaičių } \\
\text { kretingiškių } \\
\text { šaltiniuose }\end{array} \\
\text { ŠVŽŽ } 1\end{array}$} & \multicolumn{2}{|c|}{$\begin{array}{c}\text { Šiaurės žemaičių telšiškių } \\
\text { šaltiniuose }\end{array}$} \\
\hline & & $T \check{T S} T$ & ŠŽT \\
\hline $\begin{array}{l}\text { su bendrosios ir momentinès laiko } \\
\text { reikšmės jungiamaisiais žodžiais }\end{array}$ & $1308(91,4 \%)$ & $551(91,68 \%)$ & $159(93,53 \%)$ \\
\hline su ribos reikšmės jungiamaisiais žodžiais & $123(8,6 \%)$ & $50(8,32 \%)$ & $11(6,47 \%)$ \\
\hline IŠ VISO & $1431(100 \%)$ & $601(100 \%)$ & $170(100 \%)$ \\
\hline
\end{tabular}

\subsection{Laiko sakiniai su bendrosios ir momentinès laiko reikšmès jungiamaisiais žodžiais}

Šio tipo laiko sakiniuose vartojamų prijungimo rodiklių reikšmè būna arba gana abstrakti ir žymi bendrą laiko nuorodą, arba paryškina veiksmo momentą. Apibendrintam dviejų veiksmų laiko santykiui nusakyti gali būti pasitelkiami jungiamieji žodžiai $k a$,kai', $\operatorname{kad}\left({ }^{a}\right)$, $k a i p$, kumet ,kuomet', o veiksmų betarpiškai sekai ir/ar momentiškumui - samplaikiniai ka tik, kaip tik ir vieniniai lig ,vos', tik, tujau(s) / tuo ,tuojau; ką tik', jau, vos, sau ${ }^{10}$.

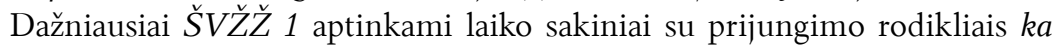
$(\sim 72,9 \%)$, kad $(\sim 12,5 \%)$ ir kaip $(\sim 10,6 \%)$ (šiaurès žemaičių telšiškių kalbèjimo tekstuose vartojimo dažnumo seka kiek skiriasi: ka, kaip, kad - plg. 2 lentelès duomenis).

Laiko sakiniais su ka, kad(a), kaip, kumet perteikiami veiksmų vienalaikiškumo arba sekos santykiai. Vienalaikiškumo santykị lemia abiejų dėmenų (arba bent vieno iš jų) tarinio raiška statinę būseną žyminčiu eigos veikslo veiksmažodžiu, plg.:

(1) k a mienộu švệit, nãkti ni kûoke baisộma nie êt 43

(2) kad î ûkan ${ }^{a}, k u \tilde{o} k^{i}$ debeŝộut $t^{a}$ ànũ (žvaigždžių) nie ni matit 110

(3) k ã p dàbã sâulieta ànệi (karosai) gộl sâulie, nêit pri mẽ̌skerẹ 434

10 Žemaičių leksikografiniuose šaltiniuose šalutinių laiko sakinių jungimo funkcija priskiriama žodeliams ka ,kai', kad ,kai' (kada šia funkcija atskirai neaptariamas), kumet (žr. KTŽ 136; 138; 195; ŠVŽŽ $1244 ; 246$; 350) bei keliais variantais - lig/lik/ lyg(u) - transponuojamam lig, kuriam nurodomas dvejopo junglumo funkciškumas, pagrịstas reikšmėmis ,vos‘ ir ,kol, iki‘

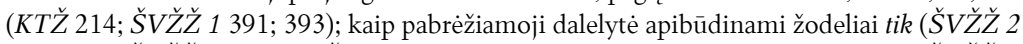
342), vos (ŠVŽŽ 2 464; KTŽ 491), kaip prieveiksmiai - žodeliai tujau(s) / tuo (ŠVŽŽ 2 370; KTŽ 458), kaip prieveiksmiai ir/ar kaip dalelytės - žodeliai jau ( $\check{S} V \check{Z ̌ Z} 1232$ ), sau (ŠVŽŽ 2 168-169; KTŽ 356). 
ŠVŽŽ 1, TŠT ir ŠŽT laiko sakinių su bendrosios ir momentinès laiko reikšmès jungiamaisiais žodžiais santykinis ir absoliutinis dažnumas

\begin{tabular}{|c|c|c|c|}
\hline Laiko sakiniai & $\begin{array}{l}\text { Šiaurės žemaičių } \\
\text { kretingiškių }\end{array}$ & \multicolumn{2}{|c|}{ Šiaurès žemaičių telšiškių šaltiniuose } \\
\hline su jungiamuoju žodžiu & ŠVŽŽ 1 & $T \check{T S T}$ & ŠŽT \\
\hline$k a(t i k)$ & $953(72,86 \%)$ & $410(74,4 \%)$ & $90(56,6 \%)$ \\
\hline kad & $163(12,61 \%)$ & $40(7,3 \%)$ & $21(13,83 \%)$ \\
\hline kaip (tik) & $138(10,55 \%)$ & $82(14,8 \%)$ & $43(27 \%)$ \\
\hline tik & $23(1,76 \%)$ & $4(0,7 \%)$ & $1(0,63 \%)$ \\
\hline $\operatorname{lig}(u)$ & $15(1,15 \%)$ & $2(0,36 \%)$ & $1(0,63 \%)$ \\
\hline kumet & $7(0,54 \%)$ & $8(1,5 \%)$ & $2(1,3 \%)$ \\
\hline jau, tujau(s)/tuo & $5(0,38 \%)$ & $3(0,5 \%)$ & - \\
\hline $\mathrm{kad}^{a}$ & $2(0,15 \%)$ & $2(0,36 \%)$ & $1(0,63 \%)$ \\
\hline vos & $1(0,07 \%)$ & - & - \\
\hline sau & $1(0,07 \%)$ & - & - \\
\hline IŠ VISO & $1308(100 \%)$ & $551(\sim 100 \%)$ & $159(\sim 100 \%)$ \\
\hline
\end{tabular}

Veiksmų laiko sutapimas neretai paryškinamas atliepiamuoju žodžiu. Juo gali būti laiko prieveiksmis, daiktavardis ar daiktavardiniu junginiu nurodoma laiko sąvoka, plg.:

(4) ka žmũogòs paklidệs $\tilde{i}$, ta gáidî̀ gệid 163

(5) mãžos gerộms e nọ̀jâu tier, ka dà bã gi.vènâm pri vệns kệta 182

(6) ka gâlv trinkâu sọ šârmo , nì kumèt nebộv ${ }^{a}$ blộuzan $^{u} 69$

(7) ta dêlč̣e $k$ a í, tọu târpo gèrã $\tilde{i}$ sọvẽšt (šieną) 113

(8) ka dèg, jãu tũo vệitûo ì pìningã 111

(9) kàd $d^{\grave{a}}$ làk, tàd $d^{a 11}$ tûoks (liežuvio) idọbệms jau pasẹdãr tam šọnệi 218

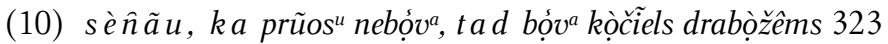

(11) kệt ${ }^{a} k \tilde{a} r t^{a}$, kad aš âugâu, pãprast ${ }^{a} s$ kọ́kn ${ }^{e}$ bộ $v^{a} 346$

Veiksmų sekos reikšmę laiko sakiniuose lemia dinaminis pagrindinio dẻmens veiksmažodis ir įvykio veikslo veiksmažodžio formų parinkimas šalutinio dèmens tarinio raiškai, pvz.:

(12) ka palêid ${ }^{a}$, ka bîegâu nọmệi 479

(13) kopũstâ, matâ, ànẹi minkštîe, ka prãded rûkte 443

(14) mệršt bẹtè̀s, $k a$ ikộnd žmũogộu 446

${ }^{11}$ Alekso Girdenio manymu, tada yra knyginis žodis (plg. Girdenis 1996: 71). 
Veiksmų seką mėgstama paryškinti pagrindiniame dėmenyje esančiu atliepiamuoju žodžiu (dažniausiai tam pasitelkiami žodeliai $i r^{12}$, (ta) tuokart, tumet, paskiau, taip), plg.:

(15) kã $p$ àn $n^{\grave{a}}$ (bitè) prisẹspâude ẹr igîel 177

(16) kã s slîâu nu tũo krî̀sla e er ilâužau kr̂aukla 336

(17) (buožgalvis) kad ộudẹga nũmet, t a tộu kãrt teprãded kuojẽeles dîkt anâm 433

(18) kãp ibrî̀, tộukârt tus lâišk ${ }^{u}$ s nup̂jâu $\hat{S}^{o} 76$

(19) kù mèt ârkli gavâ, tùm è̀ $i$ siek 174

(20) pàs $\hat{k} \tilde{a} u, k \tilde{a} p$ tievíelis nũmẹre, pasẹdalẹjûom žemẽel 104

(21) kãp ọns tìktã jau isẹlêid ${ }^{a}$, têp sau viel sau sudundieje [...] ta žẽm? 140

Nusakomos situacijos veiksmų kompaktiškumui paryškinti laiko sakiniuose pasitelkiami prijungimo rodikliai tik (tik neretai būna samplaikoje su $k a$ arba kaip), lig/lik, tujau(s). Turima medžiaga rodo, kad šie žodeliai prijungimo rodiklio funkciją ịgyja betarpišką ir (ar) netikėtą veiksmų seką nurodančiuose sakiniuose (momentinị veiksmų pobūdị juose neretai išryškina ịprastines veiksmažodžio formas pakeičiantys ištiktukai, žr. (26), (29), (30) pavyzdžius). Aptikti pavieniai žodelių vos, jau, sau atvejai (žr. (27)-(29) sakinius) $)^{13}$ gali atrodyti ginčytini ${ }^{14}$, nes ju kaip prijungimo rodiklio funkcija išryškejja tik

12 Iš pirmo žvilgsnio žodeliui ir atrodo labiau priskirtina tik pabrěžiamosios dalelytės funkcija, kuri reikšme ,net, dargi“ nurodyta $\stackrel{S}{V} V \check{Z ̌ Z ̌ ~} 1223$. Vieno iš šio straipsnio anoniminių Recenzentų

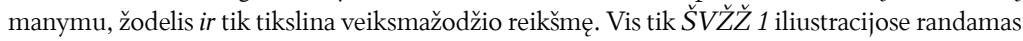
pluoštas laiko sakinių (daugiausia su kaip), kuriais nusakomas veiksmo momentas sutampa su pagrindinio dèmens veiksmažodžiu nusakomo netikèto įvykio pradžia, o pagrindinio dèmens kraštinèje pozicijoje prieš veiksmažodi esantis ir turi reikšmę ,tada / tuo momentu / tuomet / nuo tada' koreliuoja su kaip, todèl vertintinas kaip atliekantis atliepiamojo žodžio funkciją. Plg. tekste pateiktus (15) bei (16) sakinius ir dar porą pavydžių: $k \tilde{a}(p)$ pasẽna ẹr

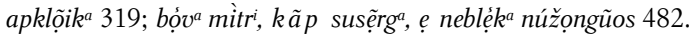

${ }^{13}$ Iki šiol ị šiuos žodelius, kaip i galinčius atlikti laiko sakinio prijungimo rodiklio funkciją, nebuvo atkreiptas dèmesys. Deja, kol nẻra paskelbtos turimų tarminių tekstų elektroninės versijos, realų tokių jau / sau vartosenos dažnumą patikrinti galima tik iš naujo nuosekliai skaitant šaltinius, o ne pasitelkus automatinę paiešką.

14 Žodeliu jau, sau kaip prijungimo rodiklių funkcija pateiktuose pavyzdžiuose nepasirodè įtikinama ir vienam iš anoniminių šio straipsnio Recenzentų. Laiko reikšmei patikslinti vartojamų pagalbinių žodžių funkcinis vaidmuo lietuvių kalbos gramatiniuose aprašuose ne kartą vertintas skirtingai. Vienas iš tokių atvejų išryškejo aptariant nefinitinius sakinius. Jablonskis, pateikęs sutrauktinių sakinių, galinčių ,turèti šalutinių sakinių jungtis” pavyzdžius ([...] Vos pasirodžius saulelei, tuojau jauti jos spinduliu galybe [...]), teigè, kad juose „tokie žodžiai, kaip: lig, ligi, kol..., [...] tèra vadinamosios kalbos dalelytės”, nes ,ju darbas čia padèti vien sakinio daliai, kuri išreikšta kitais žodžiais, tiksliaus pasižymėdinti” (Jablonskis 
pagal analogiją su kitais tam tikros struktūros (prepozicinis šalutinis dėmuo, kraštinè - šalutini dèmeni pradedanti - prijungimo rodiklio pozicija) ir semantikos (šalutiniu dèmeniu nusakomo veiksmo momentiškumas ir pagrindiniu dèmeniu nusakomo veiksmo netikètumas ir rezultatyvumas) sakiniais, sudarytais su kai(p) tik ar tik. Plg.:

(22) tik ęžgệrd ${ }^{a}$, tù jã u ãusìs pastãt e e klãusûos 37

(23) ka tik atsisied ${ }^{\circ}$ e e kèrež̂ûjẹs $i$ skrẽta vãks 289

(24) lik parvažavâu ẹš rùsejũos [Rusijos], e r apstûoje kap šúnis 391

(25) tù jãus suru.k̂âu tộu cẹggarieta ${ }^{a}$ atsẹkîeles e nuejâu 89

(26) lik tik ọns ãdgọle, tus pãtẹl ${ }^{u}$ k̂ûst 309

(27) vũos pradieje âute e nukrâč̂ûjoj 328

(28) ja u ikộnda (bitè) ẹr ànũos nèbĩe 275

(29) sau dvẹ́rati pãmete mọ̀n fìmt pri žẽmẹs 160

Žymiai dažniau minètieji žodeliai atlieka pabrěžiamosios dalelytės (intensyvumo modifikatoriaus) ar atliepiamojo žodžio funkciją. Kartais skirtingas funkcijas atliekantys tik arba lig būna aptinkami net tame pačiame sudètiniame sakinyje, plg.:

(30) tik< $<>$ ilệp $\hat{s}^{o}$ i lûova - e vĩel tik klũmpš klũmpš 398

(31) lẹg gò ons mẹrre, lẹggò tùjãu s pàt tọu malûn $n^{a}$ er ọždãre 393

ŠVŽŽ 1 (kaip ir TŠT bei ŠŽT) esama praeityje pasikartojančius veiksmus nupasakojančių laiko sakinių, kurių pagrindinio ir šalutinio dėmens tariniai išreikšti būsimojo laiko veiksmažodžių formomis ${ }^{15}$, tik kartais juose pasitelkiant pagalbinį veiksmažodị liuob ${ }^{16}$, plg.:

(32) rộdẹn $n^{i}$ ka palis, patvins, kâlns iš kâln ộndộu lộ( b) bûs 254

1957: 518). Ambrazas jiems suteike jungiamojo žodžio statusą: „Laiko reikšmei tiksliau apibrèžti vartojami jungiamieji žodžiai iki, ligi, ligi tik, prieš ir kt. einantys padalyvinès, pusdalyvinès ar dalyvinès konstrukcijos pradžioje“ (Ambrazas 1976a: 534).

15 Laiko sakinių su $\mathrm{ka} / \mathrm{kad}$ ir būtojo dažninio laiko veiksmažodžio formomis su -dav- raiška

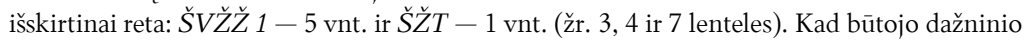
laiko formų įtraukimo ị $S$ V̌ŽŽ gal ir kiek sąmoningai buvo privengta rodo jų vartojimas tik iliustruojant retesnę leksiką, pvz.: $k$ a nebûdav ${ }^{a}$ sklêep ${ }^{a}$, i kã̂́ $\hat{c}^{o}$ diedav ${ }^{a}$ (bulves) 263; únt_ledãs ka bûdav jau vëinọ lèdžingọ, tad náks, nàgọ vadẹnûom 459.

${ }^{16}$ Apie vietoj lietuvių bendrinèje kalboje įprasto būtojo dažninio laiko formų su -dav-žemaičių vartojamą ,pagalbinį veiksmažodị l̂uob, lộub, lộb su bendratimi arba būsimuoju laiku“ žr. Pabrèža 2013: 36; Lubienè, Pakalniškienè 2015. 
Žymiai dažnesni praeityje pasikartojančius veiksmus nusakantys laiko sakiniai vien su būsimojo laiko veiksmažodžiu formomis, pvz.:

(33) k a tộu mẽdo jïms, prisẹvâlgîis ${ }^{i}$ ẹik benọiesi 426

(34) k a sâule ọselêis, bepalêis 405

(35) $k$ a dirps ${ }^{i}$ - dirps i $^{2}$ a jọkộus ${ }^{i}$ - jọkộus 242

Tokiuose sakiniuose habituali padeda atpažinti pagrindinio dèmes veiksmažodžio iteratyvumas, apibendrinto subjekto pateiktys (kalbejimas antru asmeniu apie save ir kitus) ar tam tikros su praeitimi susiejamos konkretumo nuorodos (parodomieji ar nežymimieji ịvardžiai, faziniai prieveiksmiai ar veiksmo pasikartojimą ar pabaigą žyminčios frazès), plg.:

(36) k a tik sùpíks, e kuotavûos tọu vãka 328

(37) k a parvažộus i tọu sãva darbĩkla , kàs tẹn bûs sviet $\hat{i}^{a}$ klausî̀ẹnûos 106; 311

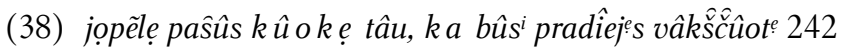

(39) $k$ a apki.ries ta lãumẹniejệms, dalisêm žệida 376

(40) kũožn's krúmslĩs ušklûs uš kûojes, k ad ệisi 343

(41) ka kùmèt jau kộkẹi ọkatnĩnkâ sọsệrĩnks váikã tệi, jãu k ũo $k^{i}$ soritîins ${ }^{i}$ bũoč 71

(42) kãp žûs, ta čè vện kàs 275

(43) ka krìkštîs, <...> tọu vãkar nugêrs, ẹ vẹs $k^{a} s 181$

Pasikartojančio praeities veiksmo raiškai sakiniuose su $\mathrm{ka} / \mathrm{kad} / \mathrm{kaip}$ vartojami ir kitokie tarinių raiškos deriniai, kai vienu iš tarinių, išreikštu būsimojo arba būtojo laiko veiksmažodžio forma, teikiama nuorodų į veiksmą praeityje. Šaltinyje pasitaiko įvairius habitualio aspektus nurodančių sakinių su tariniais, išreikštais skirtingomis veiksmažodžių formomis, plg.:

- esamojo (pagrindinis dèmuo) ir būsimojo laiko (šalutinis dėmuo):

(44) ka ẹisi kèlọ, ànũos (griežlès) bieg 283

(45) mûotrẹškâ nieks nepãded, $k$ a rẽks žemẽe ẹšârtẹ 452

- būtojo laiko (pagrindinis dèmuo) ir būsimojo ar esamojo laiko (šalutinis dèmuo):

(46) ka kvepieje, ka nueisi ì lộnk às 360

(47) žvọngieje , k a važộus, džin džâng, džin džâng 150

- būsimojo (pagrindinis dèmuo) ir būtojo laiko (šalutinis dèmuo):

(48) ka bộv $v^{a}$ suodĩb ${ }^{a}$ s, vẹsšt $t^{a}$ sãrks, kudakộus 267

(49) k a mès màžesnè bùvûom <...> - ẽsêm pakn̂uiseniêt 323 


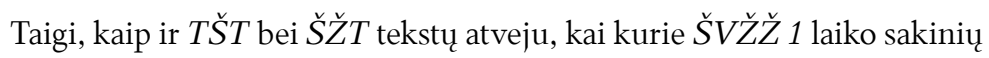
vartojimo modeliai rodo, kad ịprastinių ar veiksmų pasikartojimo praeityje raiškos laiko sakiniais būdai apima ne vien galimai ryškų ir sugramatintai žymimą praeities veiksmų dažnumą (plg. Habitual Past), bet ir ịpročio (Habitual) bei apibendrinančio pobūdžio veiksmų (Habitual Generic) $)^{17}$ telkinius, kurie naratyvuose gali būti ịvairiomis gramatinèmis priemonèmis priartinami prie dabarties ar visuomet galimai vyksiančių situacijų.

Laiko sakiniai su į ateitị orientuotų veiksmų raiška sudaromi ne vien su būsimojo-būsimojo, bet ir su būsimojo-esamojo ar būsimojo-liepiamosios nuosakos veiksmažodžiu formomis išreikštais tariniais. Šio tipo sakinių semantika susijusi su ateities planavimu (pažadais, grasinimais, prašymais ir pan.), pvz.:

(50) k a bepraḳ̣̂̂rs kùmèt, viel ọstaisî̀̂̂â 309

(51) kad aš numệr $\widehat{s}^{o}$ - vẹ̀sk $k^{a ̀ s}$ anệms 446

(52) kad paĩm $\hat{s}^{o}$ maišíkkli - abọ́do ẹšrũksẹtâu 410

(53) k a sọockin̂n $\hat{S}^{o}$, tùjãu atsẹsies ${ }^{i} 137$

(54) ka pradies vệrt sọ kũnkộlo - nukêlk 352

(55) ka parệisi, padunksnûok i lộnga ẹr ilêișo 140

(56) kad ẹisi, kèpšteriek ẹ mộn 288

Sakinių su bendrosios ir momentinès laiko reikšmès prijungimo rodikliais šalutinio dèmens tarinys paprastai būna išreikštas asmenuojamąja veiksmažodžio forma. Ši tendencija būdinga ir ŠVŽŽ 1 teikiamos medžiagos visumai, išskyrus keletą (pa)dalyvinio laiko sakinio atvejų, plg.:

(57) kad ọns grĩžes nọmệi, tuo senẽle nebibộva 206

(58) ja u mệrštộnt mùš i lệnt 446

(59) $k a$ (šeškas) vẹštûoms smârvẹ pà le dọ̃us, vẹ́št ${ }^{a}$ s nulãkst $t^{a} 368$

(60) aš lig parẽjus ${ }^{i}$, tùjãu atsisied 155

ŠVŽŽ 1 prijungiamųių laiko sakinių su bendrosios ir momentinès laiko reikšmès jungiamaisiais žodžiais gramatinių ir pozicinių modelių pasiskirstymas parodytas 3-8 lentelèse. Didžiausią jų dalị sudaro sudètiniai laiko sakiniai su to paties gramatinio laiko (būtojo-būtojo, esamojo-esamojo ar būsimojo-būsimojo) veiksmažodžio formomis pagrindiniame ir šalutiniame dėmenyse. Pavyzdžiui, sakinių su ka modeliai dažniausiai sudaromi su esamojo-esamojo (439 vnt./ 46,1\%), būtojo-būtojo (251 vnt./ 26,3\%) ir

17 Apie gramatinio laiko ir aspekto prototipus ir jų telkimosi galimybes bei apie visoms habitualio situacijoms būdingą imperfektyvumą žr. Croft 2012: 135; 140. 
būsimojo-būsimojo ${ }^{18}$ (170 vnt./ 17,85\%) laiko veiksmažodžių formomis išreikštais tariniais. Vienodo sintaksinio plano tarinių parinktis turintiems laiko sakiniams būdinga laisva šalutinio dèmens pozicija (pvz., prepozicinių $k a$ $\mathrm{V}_{\mathrm{ES}}, \mathrm{V}_{\mathrm{ES}}$ modelio sakiniu yra $68,1 \%$, postpozicinių $-25,5 \%$, interpoziciniu 6,4\%; prepozicinių $k a \mathrm{~V}_{\text {вот, }} \mathrm{V}_{\text {вот }}$ modelio $-69,3 \%$, postpoziciniu $-23,5 \%$, interpozicinių $-7,2 \%$ ). Šalutinio dèmens pozicija ịvairi perteikiant ir veiksmų vienalaikiškumo, ir sekos santykius, plg.:

(61) k a âugâu, bọvâu tũoki lašẹnẹn 373

(62) tũok baidi.klût's, ka âuga, bộv ${ }^{a}$, neklãus e ni vệin ${ }^{a} 42$

(63) àn $n^{\grave{a}}$ bộ $v^{a}$ drimb $\hat{i n}^{a}$, kad âug 133

(64) k a pradieje mêrdîtet, pažàdẹnâu vẹ̀s ${ }^{u} S 431$

(65) ti(k) gegúte, ka i sãva vẹiit nuejâu, kukãv 176

(66) tûoks nẹižílis atsẹ̀rộnd, $k$ a nũtrin ${ }^{i} 473$

Vienodo sintaksinio plano tarinių parinktys būdingos ir laiko sakiniams su kad, kaip ir kumet. Pozicinè šalutinio dèmens pirmenybe pagrindinio dèmens atžvilgiu taip pat ryški: prepoziciniai sakiniai su $k a$ sudaro 70,6\%, su $k a d\left({ }^{a}\right)-82,4 \%$, su kaip - 79\%, o prepoziciniai su kumet bei su momentinės reikšmės prijungimo rodiklių funkciją atliekančiais tik, lig, jau, tujau(s), vos, sau $-100 \%$. Tokia laiko sakinių su momentinès reikšmès prijungimo rodikliais struktūra sietina su jau minètu šiuc žodelių daugiafunkciškumu ir kalbančiojo polinkiu rinktis ikonišką ${ }^{19}$, o ne inversinį veiksmų sekos nusakymą, plg.:

(67) tik pàjĩmk (katiną) ọžcoudegũos, tù jã u brieš 75

(68) jâu pasệbệng anâm lãiks, ẹr ộns tùjãu pàt dêl 123

Prepozicinių laiko sakinių su bendrosios ir momentinès laiko reikšmès jungiamaisiais žodžiais gausą - 74,16\% (žr. 7 ir 8 lenteles) - galejo kiek nulemti ir leksikografiniam šaltiniui svarbios medžiagos atranka, - aptariamo tipo laiko sakiniu prepozicija kur kas silpniau išreikšta ištisini kalbos srautą fiksuojančiuose $\check{S} \check{Z} T(56,6 \%)$ ir TŠT $(42,3 \%)$ tekstuose.

18 Didesnè pastarųų dalis (132 vnt./ 13,85\%) perteikia su habitualiu, o ne su konkrečia ateitimi susijusius santykius.

19 Ikoniškumas sietinas su polinkiu įforminti kalbines struktūras pagal panašumą su patirtimi, t. y. chronologinio eiliškumo tvarka (plg. Croft 1990: 164; 194). Esant ikoniškai motyvacijai (t. y. atitikimui tarp lingvistinès struktūros ir lingvistinès reikšmès) sudètinio sakinio dèmenų tvarka atitinka loginius ryšius tarp veiksmų (plg. Haiman 1985: 11, Cristofaro 2005: 8). 
$\frac{\frac{0}{5}}{\frac{5}{2}}$

\begin{tabular}{|c|c|c|c|c|c|c|c|c|c|c|c|c|c|c|c|c|c|c|c|}
\hline \multirow{4}{*}{-N } & 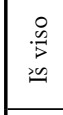 & $\begin{array}{r}8 \\
10 \\
\pm \stackrel{10}{\Xi} \\
\end{array}$ & $\begin{array}{c}2 \\
0 \\
10 \\
10 \\
10 \\
0\end{array}$ & 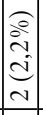 & 1 & 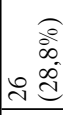 & $\begin{array}{l}2 \\
\therefore \\
= \\
= \\
=\end{array}$ & 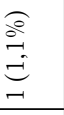 & & 1 & 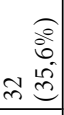 & $\mid \begin{array}{c}0 \\
0 \\
0 \\
0 \\
0 \\
10 \\
\end{array}$ & 1 & 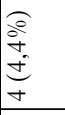 & 1 & 1 & 1 & & ஃ \\
\hline & 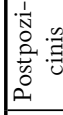 & $\begin{array}{l}\widehat{O} \\
\text { in } \\
\text { in } \\
\text { in }\end{array}$ & 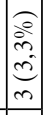 & 1 & 1 & \begin{tabular}{|l} 
\\
$\vdots$ \\
$\vdots$ \\
+ \\
+ \\
+ \\
\end{tabular} & 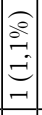 & 1 & 1 & 1 & 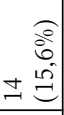 & $\mid \begin{array}{c}a \\
\grave{a} \\
c \\
c \\
\sim\end{array}$ & 1 & 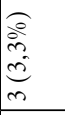 & 1 & 1 & 1 & 1 & 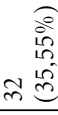 \\
\hline & 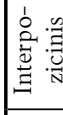 & 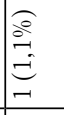 & 1 & 1 & 1 & $\begin{array}{l}2 \\
\varrho \\
= \\
= \\
-1\end{array}$ & 1 & 1 & 1 & । & $\begin{array}{l}\widehat{\partial} \\
\stackrel{2}{1} \\
\hat{e} \\
0\end{array}$ & 1 & 1 & 1 & 1 & 1 & 1 & & $\begin{array}{l}\widehat{\varrho} \\
\stackrel{a}{\infty} \\
\infty \\
\infty\end{array}$ \\
\hline & 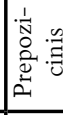 & $\begin{array}{l}\hat{\varrho} \\
\stackrel{2}{\alpha} \\
\infty \\
\infty \\
\infty\end{array}$ & 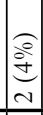 & 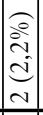 & 1 & 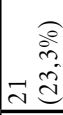 & 1 & 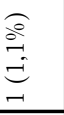 & 1 & I & 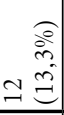 & 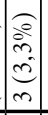 & & 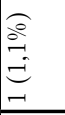 & 1 & 1 & 1 & 1 & $\begin{array}{r}a \\
\text { in } \\
10 \\
\circ \stackrel{0}{0} \\
\end{array}$ \\
\hline \multirow{4}{*}{ 包 } & 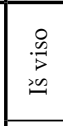 & 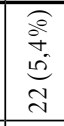 & 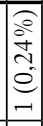 & 1 & 1 & 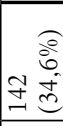 & 1 & 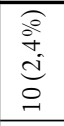 & 1 & I & $\begin{array}{rl} & \\
& 8 \\
8 & 0 \\
0 & 10 \\
& 0 \\
\end{array}$ & 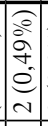 & $\begin{array}{l} \\
\stackrel{2}{a} \\
i \\
c \\
a\end{array}$ & 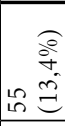 & $\begin{array}{l} \\
\\
\end{array}$ & 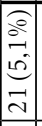 & 1 & 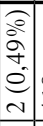 & 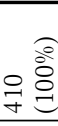 \\
\hline & 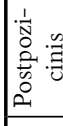 & ब̊ & 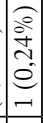 & | & 1 & $m \stackrel{\infty}{\sigma}$ & 1 & 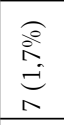 & 1 & $\mathrm{I}$ & $\begin{array}{r}\overparen{\odot} \\
\pm \stackrel{\infty}{=} \\
\end{array}$ & 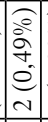 & 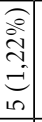 & 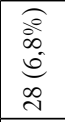 & \begin{tabular}{|l} 
\\
1 \\
\end{tabular} & 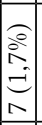 & \begin{tabular}{|l|} 
\\
\end{tabular} & 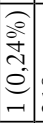 & 웜 \\
\hline & 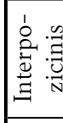 & 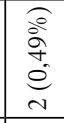 & 1 & 1 & 1 & 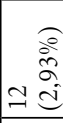 & 1 & $\begin{array}{l}\hat{\varrho} \\
\stackrel{0}{e} \\
\stackrel{n}{e}\end{array}$ & 1 & 1 & 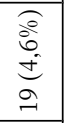 & 1 & 1 & 1 & 1 & 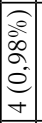 & 1 & 1 & $\begin{array}{l}\widehat{a} \\
\infty \\
\infty \\
0 \\
o \\
o\end{array}$ \\
\hline & 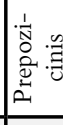 & 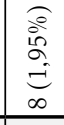 & 1 & 1 & 1 & $\begin{array}{r}\varrho \\
\text { वे } \\
\text { in }\end{array}$ & 1 & 1 & 1 & $\mathrm{I}$ & 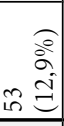 & & 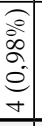 & 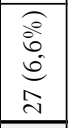 & 1 & 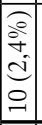 & \begin{tabular}{|l|} 
\\
\\
\end{tabular} & 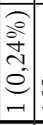 & 응 \\
\hline \multirow{4}{*}{${ }_{i}^{-N}$} & 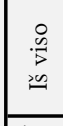 & 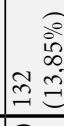 & 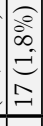 & \begin{tabular}{|l|} 
\\
$\varrho$ \\
$a$ \\
$e$ \\
$\hat{a}$ \\
\end{tabular} & 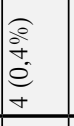 & 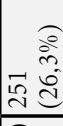 & 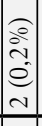 & 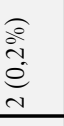 & 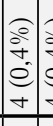 & 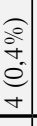 & 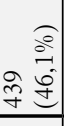 & 1 & \begin{tabular}{|c|}
0 \\
0 \\
0 \\
0 \\
0 \\
0 \\
\end{tabular} & 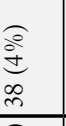 & \begin{tabular}{|c|} 
\\
\hdashline \\
\hdashline \\
$e$ \\
-1 \\
\end{tabular} & 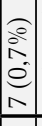 & 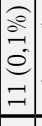 & \begin{tabular}{c} 
\\
\hdashline \\
$\infty$ \\
0 \\
$\infty$ \\
$\infty$
\end{tabular} & مٌ \\
\hline & 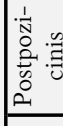 & 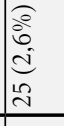 & 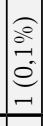 & 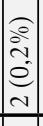 & $\begin{array}{l}\hat{e} \\
\stackrel{a}{e} \\
e \\
-1\end{array}$ & 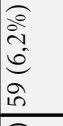 & 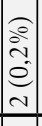 & 1 & 1 & 1 & 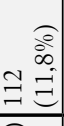 & & $\begin{array}{l}0 \\
0 \\
0 \\
e \\
0 \\
0\end{array}$ & 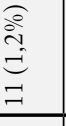 & 1 & 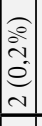 & 1 & 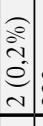 & 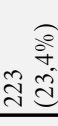 \\
\hline & 总: & $\begin{array}{l}\mathfrak{e} \\
\vdots \\
e \\
e \\
i \\
\end{array}$ & 1 & & 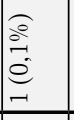 & 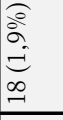 & 1 & 1 & $\mid \begin{array}{c}0 \\
\varrho \\
- \\
0 \\
e \\
-1 \\
\end{array}$ & & $\begin{array}{l}\text { aे } \\
\text { aे } \\
\text { cे } \\
\text { d. } \\
\text { d }\end{array}$ & & $\begin{array}{c}\varrho \\
\varrho \\
- \\
e \\
-1 \\
\end{array}$ & $\begin{array}{l}\hat{0} \\
0 \\
0 \\
0 \\
-1\end{array}$ & 1 & 1 & 1 & 1 & $\begin{array}{l}\text { a } \\
\text { i } \\
\text { in }\end{array}$ \\
\hline & 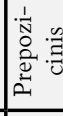 & $\begin{array}{r}8 \\
8 \\
8 \\
0\end{array}$ & 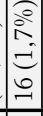 & $\mid \begin{array}{c}0 \\
2 \\
0 \\
e \\
- \\
\end{array}$ & 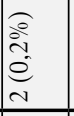 & 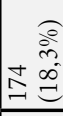 & & $\begin{array}{l}\text { @े } \\
\text { c̀ } \\
\text { é } \\
\text { v }\end{array}$ & 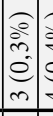 & 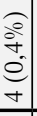 & 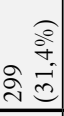 & 1 & 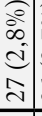 & 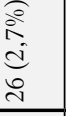 & 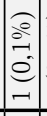 & \begin{tabular}{c}
0 \\
\hdashline \\
$i n$ \\
$e$ \\
10 \\
10
\end{tabular} & $\begin{array}{c}\varrho \\
\varrho \\
-1 \\
e \\
-1 \\
\end{array}$ & $\begin{array}{l}0 \\
0 \\
0 \\
0 \\
0 \\
0\end{array}$ & 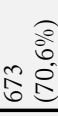 \\
\hline 总 & 墨 & $\frac{p^{n}}{p^{n}}$ & 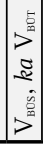 & 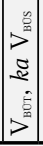 & 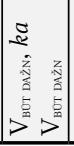 & 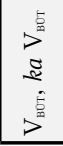 & 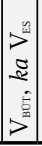 & 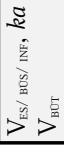 & 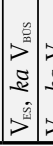 & 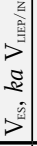 & $\frac{j}{p^{3}}$ & 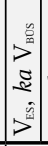 & 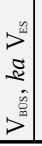 & 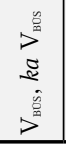 & 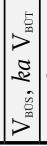 & 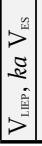 & 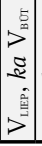 & 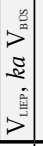 & $\begin{array}{l}0 \\
\infty \\
\infty \\
\infty\end{array}$ \\
\hline 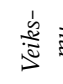 & 芯 & 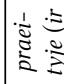 & & & & & & & & & 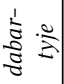 & בั & & & & & & & \\
\hline
\end{tabular}


Jūratė PAJÉDIENÉ. Sudètiniai prijungiamieji laiko sakiniai šiaurẻs žemaičių tarmėje ..

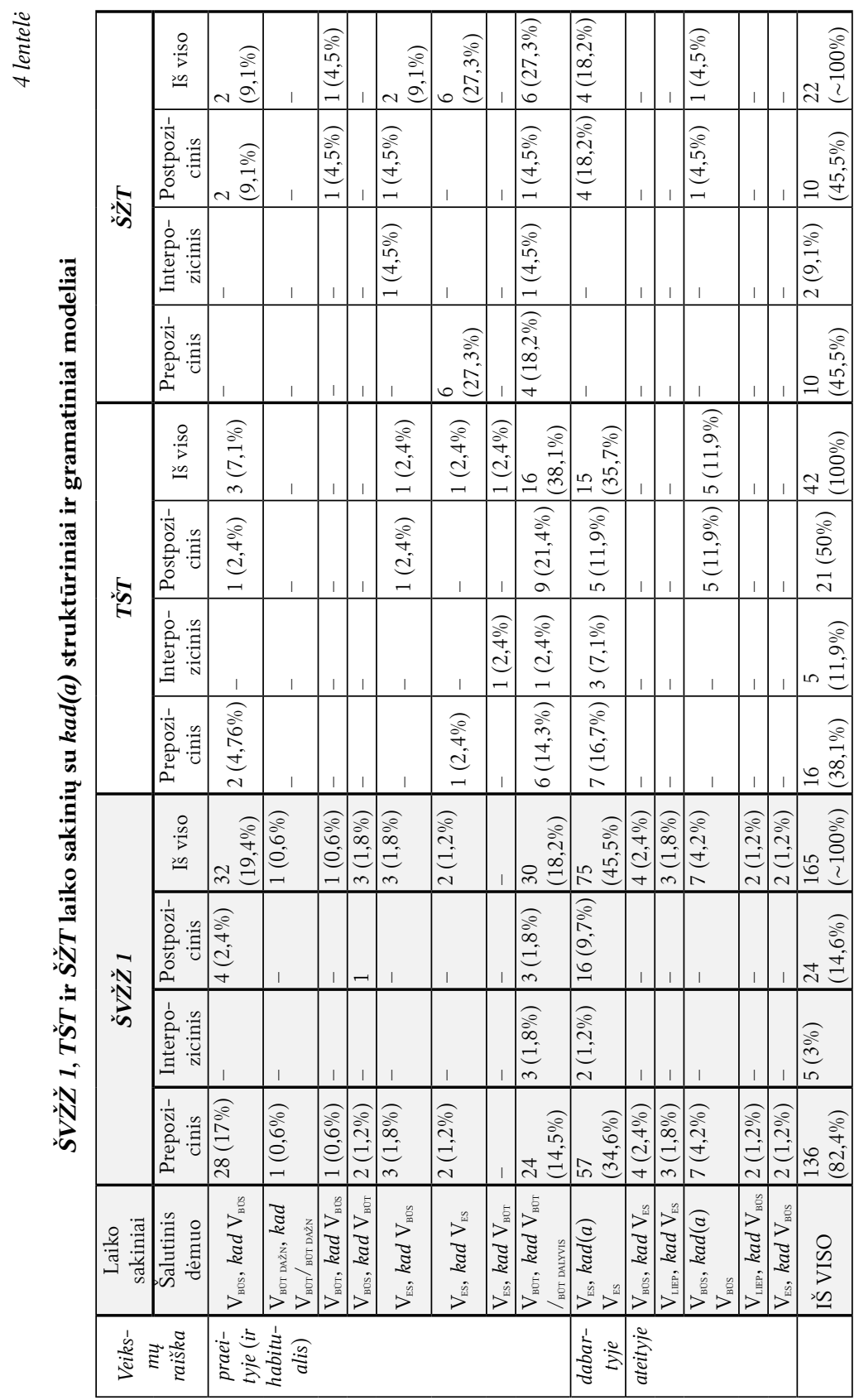


$\frac{\frac{2}{2}}{\frac{5}{2}}$

\begin{tabular}{|c|c|c|c|c|c|c|c|}
\hline \multirow{4}{*}{ 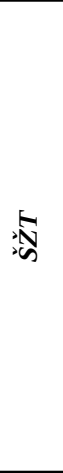 } & $\begin{array}{c}8 \\
. \infty \\
5 \\
>\infty \\
\infty\end{array}$ & 1 & 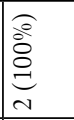 & 1 & 1 & 1 & $\underbrace{\stackrel{8}{8}}_{\text {을 }}$ \\
\hline & 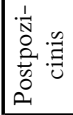 & 1 & 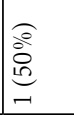 & 1 & 1 & 1 & 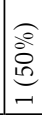 \\
\hline & 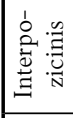 & 1 & 1 & 1 & 1 & I & । \\
\hline & 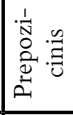 & 1 & 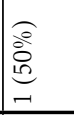 & 1 & 1 & 1 & $\begin{array}{l}\widehat{\varrho} \\
8 \\
0 \\
0 \\
-1\end{array}$ \\
\hline \multirow{4}{*}{ 曶 } & 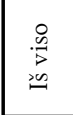 & 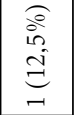 & 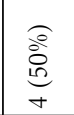 & 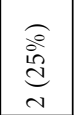 & 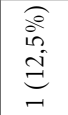 & 1 & 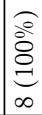 \\
\hline & 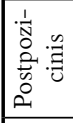 & 1 & 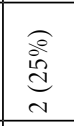 & 1 & 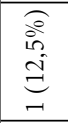 & 1 & 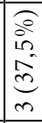 \\
\hline & 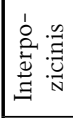 & 1 & 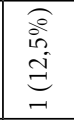 & 1 & 1 & 1 & 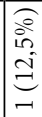 \\
\hline & 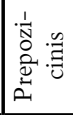 & 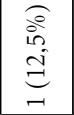 & 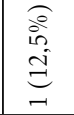 & 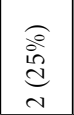 & 1 & 1 & 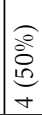 \\
\hline \multirow{4}{*}{ 瓷 } & 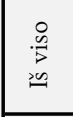 & I & 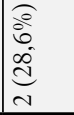 & $\begin{array}{l}\stackrel{o}{a} \\
\text { à } \\
\text { dy } \\
\text { m }\end{array}$ & 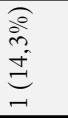 & 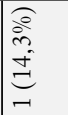 & 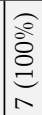 \\
\hline & 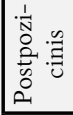 & 1 & 1 & 1 & 1 & 1 & 1 \\
\hline & 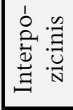 & 1 & 1 & 1 & 1 & 1 & 1 \\
\hline & 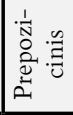 & 1 & $\begin{array}{c}0 \\
o \\
b \\
\infty \\
d \\
d \\
d\end{array}$ & $\begin{array}{l}\hat{o} \\
\text { à } \\
\text { ju } \\
\text { m }\end{array}$ & 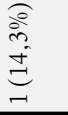 & 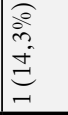 & 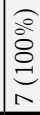 \\
\hline 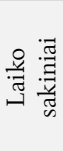 & 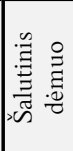 & 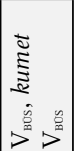 & 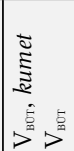 & 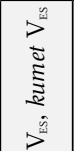 & 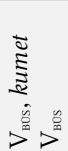 & 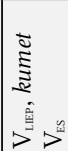 & 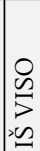 \\
\hline 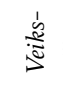 & [. & 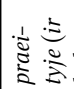 & 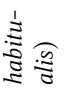 & 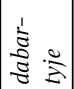 & $\frac{.}{\frac{\pi}{3}}$ & & \\
\hline
\end{tabular}


Jūratė PAJÉDIENÉ. Sudètiniai prijungiamieji laiko sakiniai šiaurės žemaičių tarmėje ..

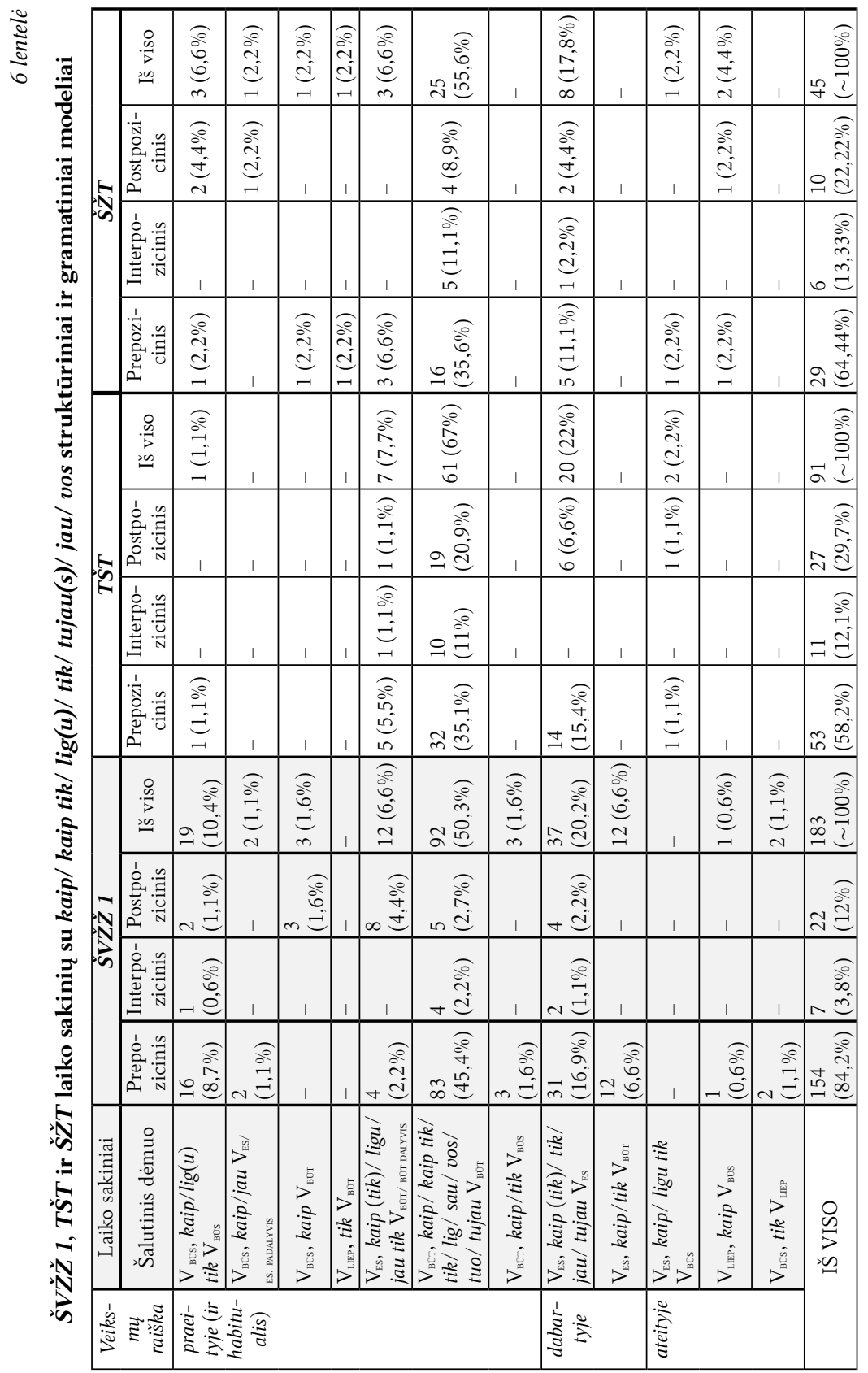




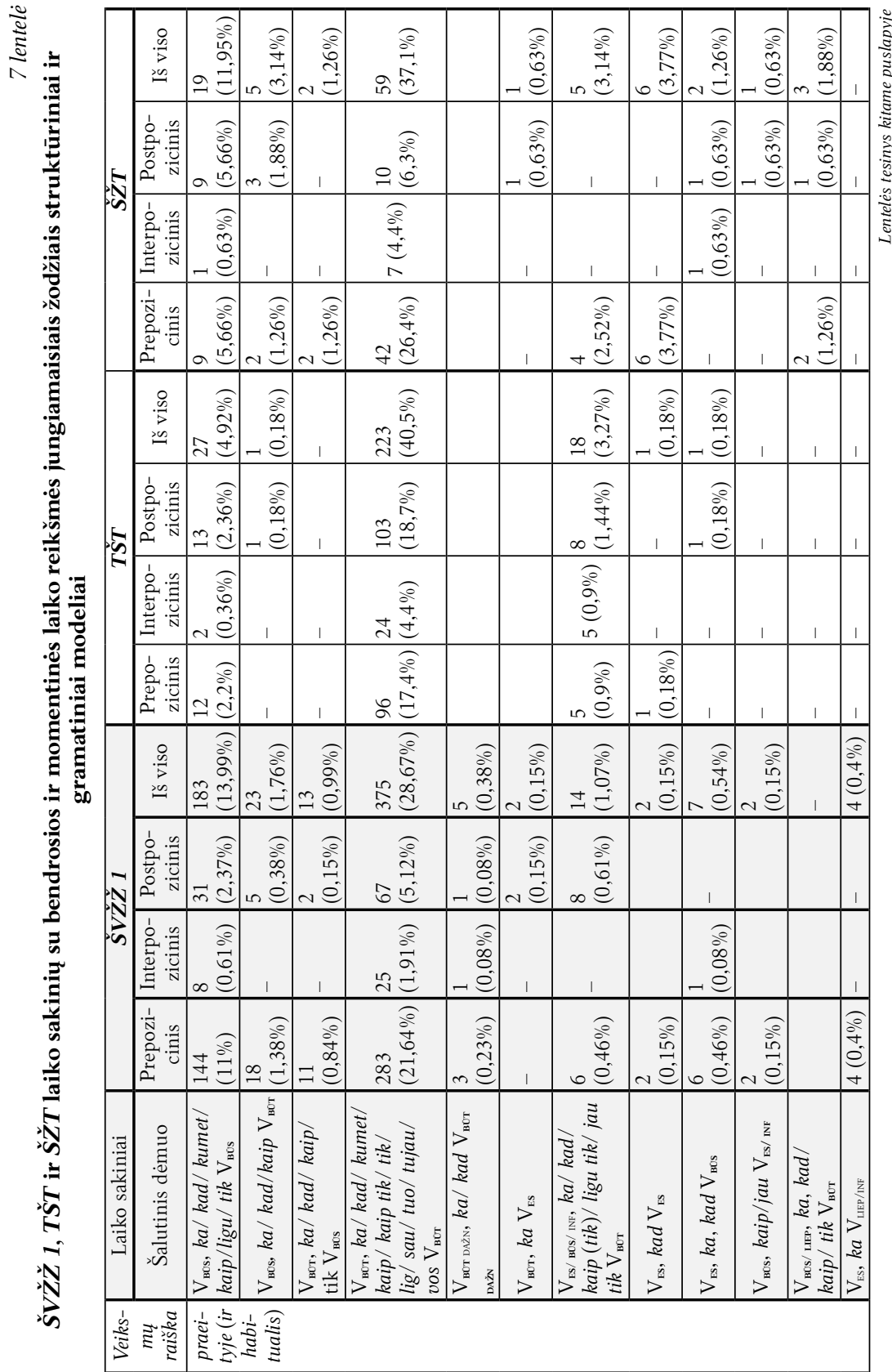




\begin{tabular}{|c|c|c|c|c|c|c|c|c|c|c|c|c|}
\hline \multirow{4}{*}{ - } & 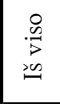 & 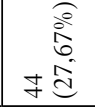 & & & 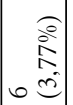 & 1 & & & & 1 & 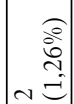 & 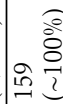 \\
\hline & 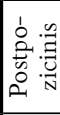 & 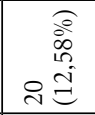 & & & 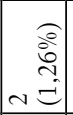 & 1 & 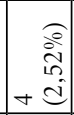 & & & 1 & 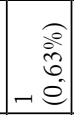 & ले \\
\hline & 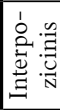 & $\begin{array}{l}\stackrel{\varrho}{\circ} \\
\dot{J} \\
\therefore\end{array}$ & & & 1 & 1 & 1 & & & 1 & 1 & 용 \\
\hline & 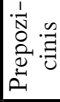 & $\begin{array}{l}\stackrel{0}{\ominus} \widehat{\circ} \\
=\hat{\sigma}\end{array}$ & & & $\begin{array}{r}2 \\
\stackrel{2}{1} \\
+2 \\
\end{array}$ & 1 & $\begin{array}{r}\widehat{\varrho} \\
\stackrel{0}{0} \\
-0\end{array}$ & & & 1 & 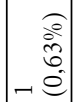 & 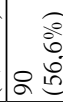 \\
\hline \multirow{4}{*}{5} & 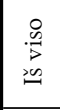 & $\begin{array}{l}\widehat{\stackrel{\rho}{े}} \\
\infty \\
\infty \\
\infty\end{array}$ & & & $\begin{array}{r}\overparen{0} \\
\stackrel{0}{N} \\
+\stackrel{e}{e} \\
\end{array}$ & a & & & & 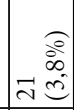 & $\left|\begin{array}{rr} & a \\
0 & 0 \\
2 & 0 \\
\sim & 0\end{array}\right|$ & 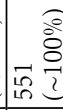 \\
\hline & $\begin{array}{l}1 \\
0 \\
0 \\
0\end{array}$ & 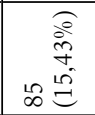 & & & 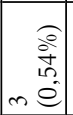 & $\begin{array}{l}\hat{o} \\
\text { aे } \\
\text { é }\end{array}$ & me & & & 돌 & 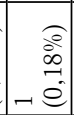 & 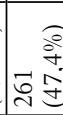 \\
\hline & 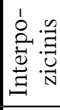 & $\begin{array}{c}\hat{\circ} \\
\text { बे }\end{array}$ & & & 1 & 1 & 1 & & & 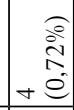 & I & 官 \\
\hline & 方 & 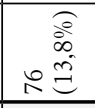 & & & 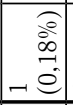 & $\begin{array}{r}\stackrel{2}{N} \\
+0 \\
\end{array}$ & 离 & & & $\begin{array}{c}\stackrel{\varrho}{\circ} \\
\stackrel{\infty}{=}=\end{array}$ & $\mid \begin{array}{r}a \\
\infty \\
-1 \\
-0\end{array}$ & 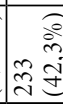 \\
\hline \multirow{4}{*}{$\begin{array}{l}-1 \\
-N \\
-N \\
-\infty \\
-\infty\end{array}$} & 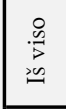 & 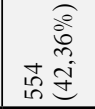 & 워 & 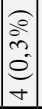 & 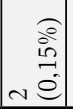 & बे & 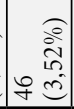 & 욜 & in & {$\left[\begin{array}{r}0 \\
\vdots \\
0 \\
= \\
=\end{array}\right.$} & $=\begin{array}{r}\widehat{e} \\
\dot{+} \\
= \\
=\end{array}$ & $\begin{array}{ll} & 0 \\
\infty & 8 \\
0 & 0 \\
0 & 2\end{array}$ \\
\hline & 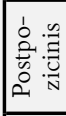 & 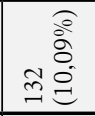 & & 1 & 1 & $\begin{array}{l}8 \\
8 \\
0 \\
0 \\
0\end{array}$ & 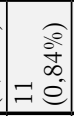 & 1 & & 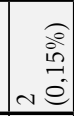 & 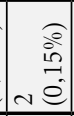 & 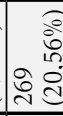 \\
\hline & 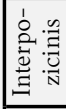 & 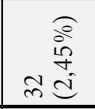 & & 1 & 1 & $\begin{array}{r}0 \\
0 \\
-0 \\
-0 \\
0\end{array}$ & $\begin{array}{r}\widehat{\varrho} \\
\infty \\
-0 \\
-0\end{array}$ & 1 & & 1 & 1 & $\begin{array}{r}a \\
\infty \\
i \\
0 \\
0 \\
0\end{array}$ \\
\hline & 竞 & 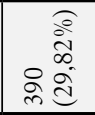 & ڤั่ & 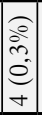 & 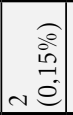 & लव & 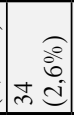 & 量 & $\mathrm{d}$ & 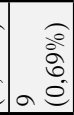 & 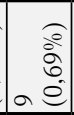 & 总 \\
\hline 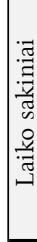 & 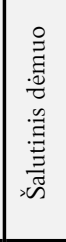 & 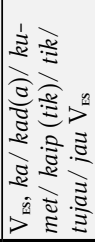 & 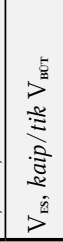 & 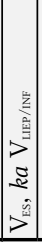 & 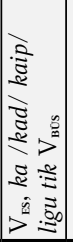 & 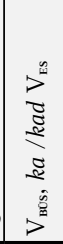 & 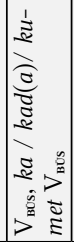 & $\frac{>^{\frac{m}{3}}}{\frac{8}{8}}$ & 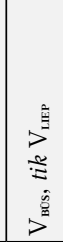 & 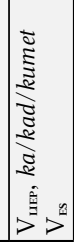 & 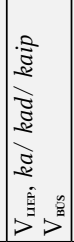 & $\begin{array}{l}0 \\
\infty \\
\infty \\
\infty\end{array}$ \\
\hline$\frac{1}{3}$ & 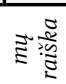 & $\frac{1}{3}$ & & $\frac{.0}{\frac{\pi}{3}}$ & & & & & & & & \\
\hline
\end{tabular}




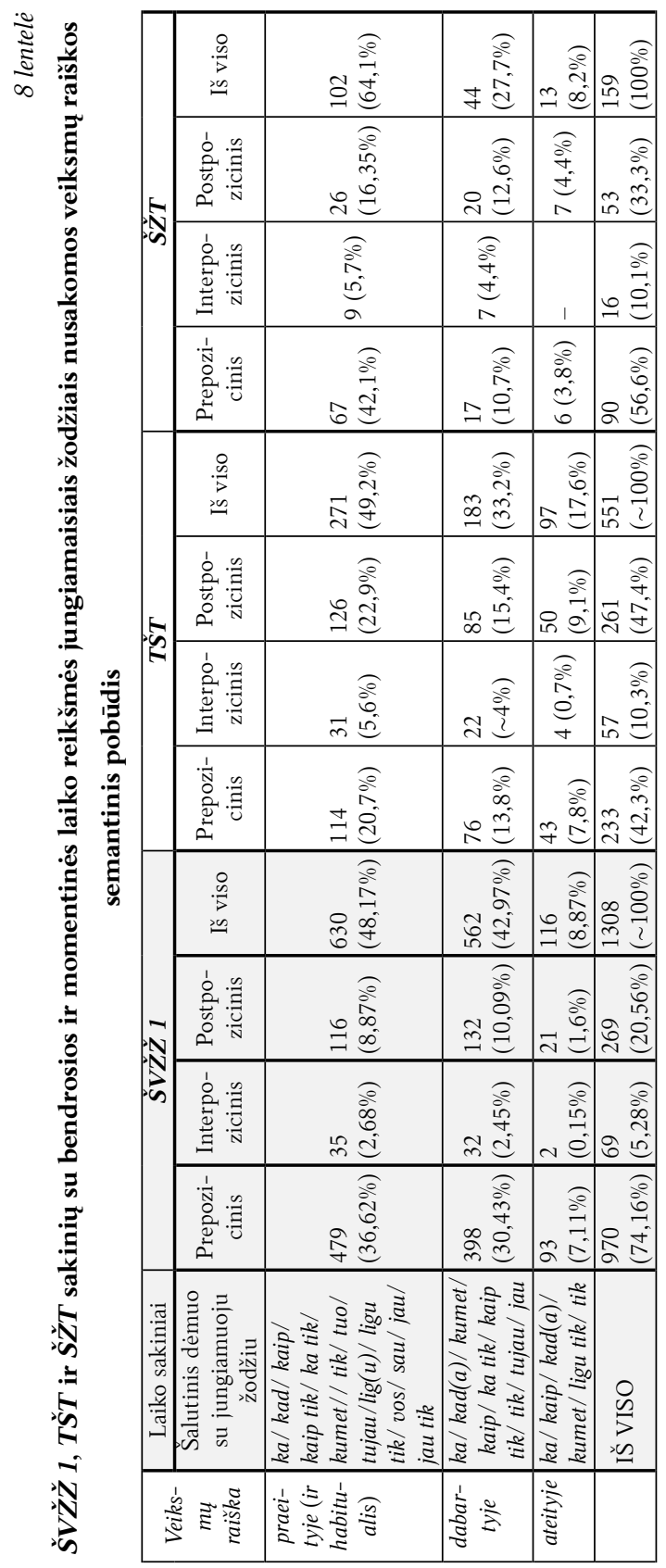


Sugretinus šiaurès žemaičių kretingiškių ir telšiškių patarmių šaltiniuose rastų sudètinių sakinių su bendrosios ir momentinės laiko reikšmės prijungimo

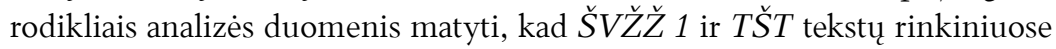
laiko sakiniai, skirti praeities ar apibendrinimo situacijų nusakymui, vartojami panašiu santykiniu dažnumu $\sim 48,7( \pm 0,5) \%$. ŠVŽŽ 1 ir $\check{S} Z ̌ T$ laiko sakiniais panašiu santykiniu dažnumu $\sim 8,55( \pm 0,35) \%$ realizuojama ateities situacijas apibūdinančių veiksmų santykio raiška (žr. 8 lentelę).

Vertinant laiko sakinių struktūrinių modelių skirtinguose žemaitiškų tekstų sąvaduose visumas matoma bendra tendencija aptarto tipo sakinius vartoti prepoziciškai. Tik $T S ̌ T$, kurio tekstams būdingas visiškai autentiškas kalbos srautas (pokalbiai buvo įrašinejjami paslèptu mikrofonu), stebima šiek tiek gausesnė postpozicinių $(47,4 \%)$ nei prepozicinių ${ }^{20}(42,3 \%)$ laiko sakinių vartosena. ŠŽT (šiame šaltinyje pateikiami pokalbiai, kurie buvo ịrašinėjami atvirai; respondentai - vyriausios kartos) santykinai daugiausia esama prepozicinių laiko sakinių (56,6\%). Dar ryškesnè tendencija vartoti

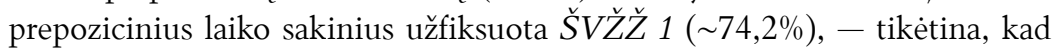
tokią laiko sakinių struktūrinių modelių tendenciją galëjo nulemti taip pat vyresnis respondentų amžius bei leksikografinis šio šaltinio profilis, pagrịstas išskirtinesnès leksikos iliustracijų atranka ${ }^{21}$.

\subsection{Laiko sakiniai su ribos reikšmès jungiamaisiais žodžiais}

ŠVŽŽ 1 aptinkami laiko sakiniai su prijungimo rodikliais kol (97 vnt.), pakol (3 vnt.), lig(i), iki‘ (12 vnt.), priš (11 vnt.)22 (žr. 9 lentelę).

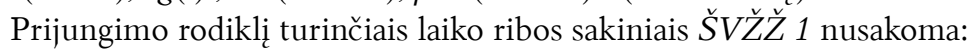

- dalinai ar pilnai sutampanti dviejų veiksmų trukmè (kai šalutinio dėmens tariniu eina eigos veikslo veiksmažodžio forma), pvz.:

(69) kuol mọ́n givi $^{a}$ gãlvà , mãrtì nèbijẽes 167

(70) dệrpk, kọl gàlì 29

(71) kọl bộv piningũ, bọ́va e draugẹškộms 130

${ }^{20}$ Sudètinio sakinio veiksmų seka ikoniškai išdèstoma ir interpoziciniuose sakinių modeliuose, plg. (20) pavyzdi.

21 Tai verifikuoti galima būtų tiriant leksikografinių ir tekstinių duomenų teikiančius kitus šios tarmès šaltinius.

22 Žemaičių leksikografiniuose šaltiniuose laiko jungtuko vaidmuo priskirtas žodeliams kol

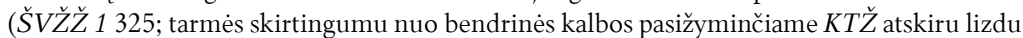
kol neaprašytas), pakol (ŠVŽŽ 2 10; KTŽ 272), lig (KTŽ 214; ŠVŽŽ 1 391; 393). Prielinksniu įvardijamam priš / pryš skiriama laiko nurodymo reikšmė (ŠVŽŽ 299$)$ ir laiko iki tam tikro kalbamojo momento nurodymo funkcija (KTŽ 320). 
9 lentele

\section{Santykinis ir absoliutinis ŠVŽŽ $1, T S ̌ T$ ir ŠŽT laiko sakinių su ribos jungiamaisiais žodžiais dažnumas}

\begin{tabular}{|c|c|c|c|}
\hline Laiko sakiniai & $\begin{array}{l}\text { Šiaurės žemaičiu } \\
\text { kretingiškių šalti- }\end{array}$ & \multicolumn{2}{|c|}{ Šiaurès žemaičių telšiškių šaltiniuose } \\
\hline su jungiamuoju žodžiu & ŠVŽŽ 1 & $T \check{T S T}$ & ŠŽT \\
\hline$(p a) k o l$ & $100(81,3 \%)$ & $47(94 \%)$ & $11(100 \%)$ \\
\hline $\operatorname{lig}$ & $12(9,8 \%)$ & $3(6 \%)$ & - \\
\hline priš & $11(8,9 \%)$ & - & - \\
\hline IŠ VISO & $123(100 \%)$ & $50(100 \%)$ & $100 \%)$ \\
\hline
\end{tabular}

- vieno veiksmo trukmè iki kito veiksmo (kai šalutinio dėmens tariniu eina įvykio veikslo veiksmažodžio forma) arba pasikartojančių veiksmų trukmè iki šalutiniu dėmeniu nusakomo veiksmo kaip rezultato, pvz.:

(72) ku ol ơzdệrbûom tọu grã ba bãd ${ }^{a}$ s e vãrgas bộv 196

(73) tọ̀i imte (kortas), kọl gâusi gíli 184

(74) tus grûobus rẽk gèrã kâište, kọl bûs gèrè 249

Trukmė iki tam tikros ribos gali būti nurodoma pagrindiniame ir šalutiniame dèmenyse (o kartais vien šalutiniame) pavartojant neigiamą veiksmažodžio formą, plg.:

(75) kộl neatligẹna tas žmũogọs tâ làtvê, tộl nieka nepadãre 392

(76) kúol nẽdege, e nejâu lãukûon 375

(77) nenoriejâu dộute lik pàt nedẹigọs 391

Laiko riba gali būti dar papildomai paryškinama atliepiamuoju žodžiu tol, pvz.:

(78) tũol dainộuṣ̂, k ũol apki.rîes 303

(79) tộl nepaẹisí, nèpakệis, kọl neatspiesi, kàs tâu ọ̃zdâuže 299

Šalutinio veiksmo kaip tam tikru pastangų ir laiko reikalaujančio rezultato reikšmė (o būsimojo laiko veiksmažodžio formų parinkties atveju papildomai paryškinamas ir veiksmų atlikimo pasikartojimo aspektas) išryškeja tautologinėse konstrukcijose, kai pagrindinio ir šalutinio dėmens tariniu eina tos pačios šaknies veiksmažodžio formos (kartais su neiginiu šalutiniame sakinyje), plg.:

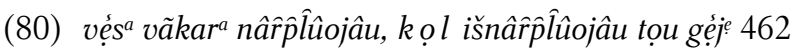

(81) vẹ́s vãkara laŝuojî̀m tus žîrn ${ }^{u}$ s, kọl išlaŝûjî̀m 373 
(82) vẹ́sa ritt $^{a}$ kakšnûojâu (dalgị), kọl iškakšnûojâu 251

(83) ọnkstệi kielâus, blon̂âaus, kuol ẹsệblon̂ââu 66

(84) pamierksi tus lẹ̀n ${ }^{\grave{s}}$, e mệrks, kọl ì̀mệrks 445

(85) tẽp kũops ${ }^{i}$ sušẹeles, kọl vãlkti prikũops 326

(86) e pavãsari, e rúdini makàsîisi par porvîn ${ }^{a}$, kọl išmakàsisi 412

(87) bàlins e bàlins, $k$ ọ́l_jãu neižbalies 45

ŠVŽŽ 1 esama ir habitualio situacijas apibūdinančių laiko ribos sakinių su dèmenų tariniais, išreikštais būsimojo-būsimojo ar esamojo-esamojo laiko veiksmažodžiu (skirtingos šaknies) formomis, plg.:

(88) kuol sâule ọsẹlês rêks dệrpte 377

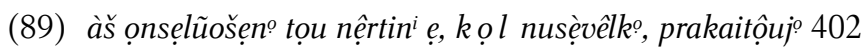

(90) sộlin, pàŝ̂âu, kọl bàiždžovẹn, sọgẽnd 182

Habitualio raišką padalyviniuose laiko sakiniuose su prijungimo rodikliu priš lemia pagrindinio dèmens tarinys su būsimojo ar esamojo laiko veiksmažodžio formomis, plg.:

(91) nọ pàŝरãu daiṇ̂̂usêm, nọ dũksêm, no dũksêm priš ẽinộnt gộlte 138

(92) priš dẹrrva vãrpộnt pabarstâu (aguonų), ẹ ẹ̌sâug 50; 223

Ateities situacijų trukmę ar svarbų momentą išryškinantys veiksmažodiniai sakiniai su kol / lig ir būsimojo-būsimojo laiko formomis aptinkami santykinai rečiau (žr. 10 lentelę) nei sakiniai (veiksmažodiniai su kol / lig ar dalyviniai su lig / priš) su liepiamąja nuosaka išreikštu pagrindinio dėmens tariniu, pvz.:

(93) lig tệi priâuks, vẹ̀sè mèdê ẹždẑ̀ûs 426

(94) lig nenusẹplâun šaukštieli, negêrk 391

(95) tas ệsied ${ }^{a}$ ìšimk pri( ̌̌ $)$ šérdam ${ }^{\grave{2}} 225$

(96) túokẹi nevĩke, priš pardộudộnt dâ gèrã rẽks kùtîntệ 357

ŠVŽŽ 1 aptinkami tik veiksmažodiniai laiko ribos sakiniai su kol ir pakol; veiksmažodiniai ir dalyviniai sakiniai su $\operatorname{lig}^{23}$ ir tik dalyviniai laiko sakiniai su priš.

${ }^{23}$ Sakinių su $\operatorname{lig}(u)$ sudarymo modeliai atitiktų dabartinès lietuvių kalbos laiko ribos sakinius su iki. 


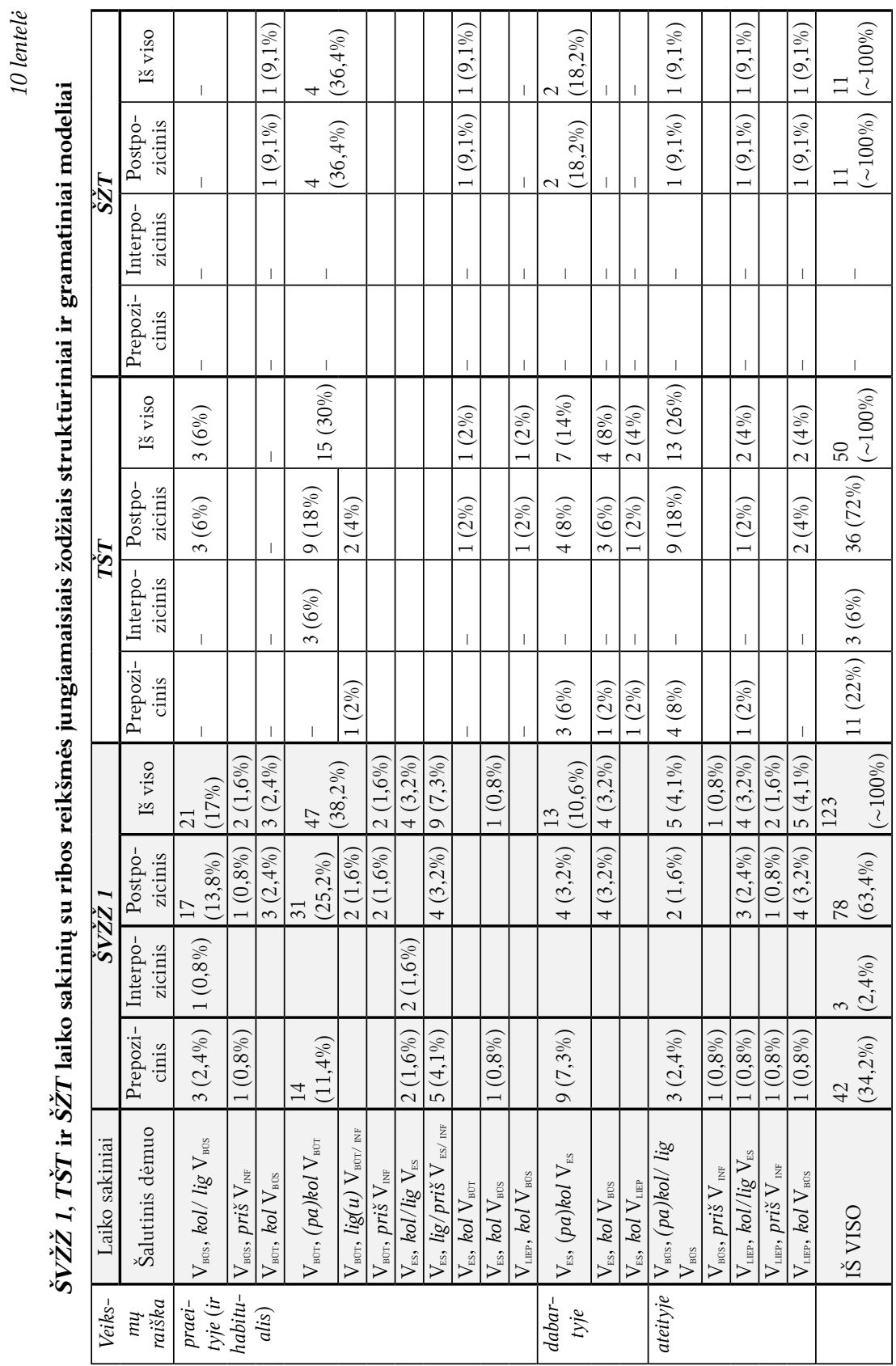


$\frac{2}{\frac{2}{5}}$

\begin{tabular}{|c|c|c|c|c|c|}
\hline \multirow{4}{*}{ - } & 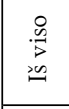 & 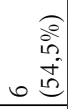 & 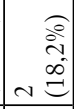 & m & $\begin{array}{r}\text { } \\
8 \\
= \\
=\end{array}$ \\
\hline & 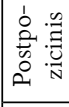 & $\begin{array}{r}8 \\
8 \\
10 \\
10 \\
10 \\
\end{array}$ & $\begin{array}{r}\stackrel{\overbrace{}}{\circ} \\
\stackrel{\infty}{\infty} \\
\sim\end{array}$ & m & $\begin{aligned} & \stackrel{8}{8} \\
= & \frac{1}{2}\end{aligned}$ \\
\hline & 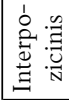 & 1 & 1 & 1 & 1 \\
\hline & 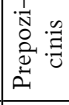 & 1 & 1 & 1 & 1 \\
\hline \multirow{4}{*}{-5} & 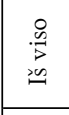 & 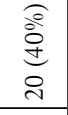 & $\begin{array}{l}\text { o } \\
\stackrel{d}{d} \\
\stackrel{m}{=}\end{array}$ & 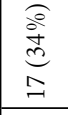 & 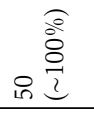 \\
\hline & 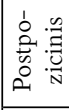 & 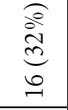 & 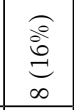 & 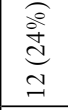 & $\begin{array}{l}\text { o } \\
\text { Na } \\
\text { D }\end{array}$ \\
\hline & 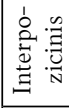 & $\underbrace{e}_{m}$ & 1 & 1 & $\underbrace{\stackrel{o}{e}}_{m}$ \\
\hline & 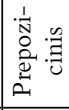 & 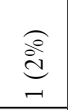 & 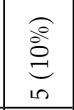 & 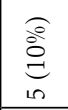 & $\begin{array}{l}\text { @े } \\
\text { ป̀ } \\
=\end{array}$ \\
\hline \multirow{4}{*}{ - } & 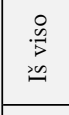 & 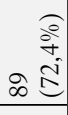 & 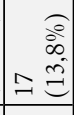 & 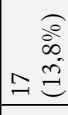 & $\approx \stackrel{8}{8}$ \\
\hline & 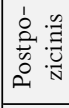 & 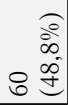 & $\begin{array}{l}\text { å } \\
\text { in } \\
\text { ê } \\
\infty\end{array}$ & $\stackrel{\overbrace{}}{\circ}$ & 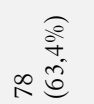 \\
\hline & 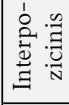 & $\begin{array}{l}\stackrel{a}{a} \\
\stackrel{+}{+} \\
\text { d } \\
m\end{array}$ & 1 & 1 & $m \stackrel{\substack{+\stackrel{+}{d}}}{a}$ \\
\hline & 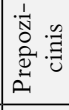 & 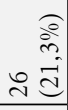 & 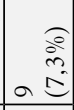 & 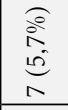 & 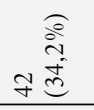 \\
\hline 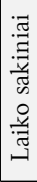 & 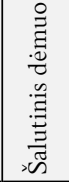 & 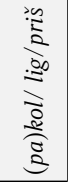 & 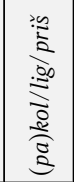 & 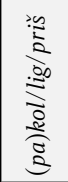 & $\begin{array}{l}0 \\
\infty \\
\infty \\
\infty\end{array}$ \\
\hline & 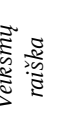 & 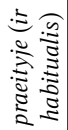 & 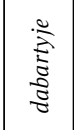 & 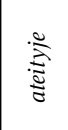 & \\
\hline
\end{tabular}


Sugretinus šiaurès žemaičių kretingiškių ir telšiškių patarmių šaltiniuose randamų laiko ribos sakinių analizès duomenis matyti, kad dažniau pasirenkami sakinių su šalutinio dèmens postpozicija modeliai: ŠVŽŽ 1 jie sudaro $63,4 \%$ visų laiko ribos sakinių, o šiaurès žemaičių telšiškių tekstuose jų yra santykinai dar daugiau: $T S ̌ T$ ju yra 72\%, o $\check{S} Z ̌ T-100 \%$ (žr. 10 ir 11 lenteles). Tai sietina su dialogiškumu ir laiko ribos nusakymui patogesniu ikonišku veiksmų sekos sudètinio sakinio dėmenimis išdėstymu.

Pagal bendrąij semantini pobūdị laiko ribos sakinių vartojimas ŠVŽ̌Ž 1 ir $\check{S} Z ̌ T$ gana panašus kalbant apie praeities situacijas: postpozicinių laiko ribos sakinių juose randama $\sim 47( \pm 2) \%$. Gali būti, kad tai susiję su abiejų šaltinių respondentu priklausymu vyriausiajai kartai ir kalbejimosi pobūdžiu.

\section{Išvados}

XX a. 7-10 dešimtmečiu šiaurès žemaičių kretingiškių kalbẻjimo fak-

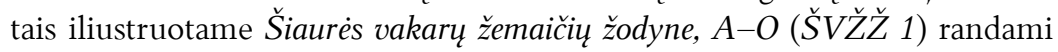
sudètiniai laiko sakiniai su prijungimo rodikliais $k a, k a d(a), k a i p, k o l, t i k$, lig ,vos', lig ,iki', priš, kumet, jau, pakol, tujau, vos, sau. Pagal prijungimo rodiklių vartojimo dažnumą panašiomis sekomis išsidèsto ir beveik to paties laikotarpio (XX a. 7-9 dešimtmečių) šiaurès žemaičiu telšiškių natūralaus kalbèjimo srautą reprezentuojančių tekstų rinkiniuose vartojami laiko sakiniai (plg. prijungimo rodiklių sekas pagal pavartojimo atvejų dažnumą $T S ̌ T: k a$, kaip, kol, kad, kumet tik, tujau, lig ,iki', lig ,vos'ir ŠŽT: ka, kaip, kad(a), kol, pakol, kumet, tik, lig ,vos').

Tirtuose šiaurès žemaičių kalbèjimo šaltiniuose sakiniai su ka, kad, kaip, kol sudaro absoliučią laiko sakinių daugumą ( 94\% ŠVŽŽ 1, 95\% TŠT ir $\sim 97 \% \check{S} Z ̌ T$ ). Kai kurie prijungimo rodikliai turi funkcinius dublikatus: žemaitiškas lig gali būti prijungimo rodikliu ne vien tik laiko ribos sakiniuose (ši lig funkcija būdinga ir dabartinei lietuvių kalbai), bet ir šalutinio veiksmo kaip atskaitos taško sakiniuose; veiksmo kaip atskaitos taško sakiniuose žodeliai lig ir tik gali atlikti prijungimo rodiklio funkciją, nors dažniau jie vartojami kaip pabrěžiamosios dalelytès; tujau(s) gali būti ir prijungimo rodiklis, ir atliepia-

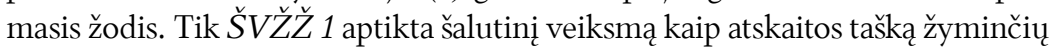
sakinių, kuriuose prijungimo rodiklio funkcija gali būti priskiriama žodeliams jau, sau, vos (iprastai jie vartojami kaip pabrèžiamosios dalelytès ar faziniai prieveiksmiai). Pavieniai šiu žodelių vartojimo atvejai iš pirmo žvilgsnio gali pasirodyti ginčytini, nes jų kaip prijungimo rodiklio funkcija išryškejja tik pagal analogiją su kitais tam tikros struktūros (prepozicinis šalutinis dèmuo ir būtinai kraštinè - šalutinị dėmenị pradedanti - prijungimo rodiklio 
pozicija) ir semantikos (nusakomos situacijos veiksmų kompaktiškumas ir netikètumas) sakiniais (dažniausiai sudaromais su kaip tik ar tik).

Visuose trijuose šaltiniuose santykinai dažniausi prijungiamieji laiko sakiniai su to paties gramatinio laiko veiksmažodžių formomis abiejuose dèmenyse, bet neretai žemaičiai renkasi ir skirtingu gramatinio laiko formų

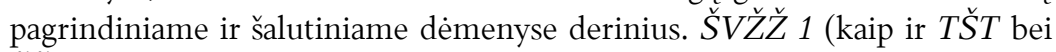
$\breve{S} Z \check{T}$ ) esama nemažai habitualiui nusakyti skirtų laiko sakinių, kurių abu tariniai išreikšti būsimojo laiko veiksmažodžio formomis. Tokios praeitį nusakančios situacijos gramatiškai žymimos kaip esančios būsimos atlikties būklēje.

Pagrindinio sakinio dèmens atžvilgiu laiko sakiniai su bendrosios ir momentinès reikšmès jungiamaisiais žodžiais santykinai dažniau vartojami prepoziciškai (ŠVŽŽ $1-74,2 \%, \check{S} Z ̌ T-56,6 \%, T \check{S} T-42,3 \%$ ), o laiko ribos sakiniai - postpoziciškai ( $\check{S} V \check{Z ̌ Z ̌ ~} 1-63,4 \%, T \check{S} T-72 \%$, o $\check{S} Z ̌ T-100 \%$ ). Toks prijungiamųių laiko sakinio modelių struktūriškumas gali būti siejamas su dialogiškumu ir natūraliame kalbos sraute labiau ịprastu ikonišku nei inversiniu dviejų veiksmų sekos išdèstymu.

\section{Šaltiniai}

$K T \check{Z}=$

$L K \check{Z} e=$

ŠVŽŽ $1,2=$

$\check{S} \check{Z} T=$

$T \check{S} T=$

\section{Literatūra}

Ambrazas, Vytautas. 1976a.

Ambrazas, Vytautas. 1976b.
Kretingos tarmès žodynas/ Aleksandravičius, Juozas. 2011: Mikulėnienė, Danguolė; Vaišnienè, Daiva, sud. Vilnius: Lietuvių kalbos institutas.

Lietuviu kalbos žodynas (t. 1-20, 1941-2002) elektroninis variantas. Antrasis elektroninis leidimas. Red. kolegija: Naktinienè, Gertrūda ir kt. Vilnius: Lietuvių kalbos institutas, 2013. Prieiga internete: www.lkz.lt

Šiaurès vakaru žemaičiu žodynas. Ylakių, Lenkimu, Mosèdžio, Skuodo, Šačiu apylinkių šnektos, $A-O ; P-\check{Z}$ / Vanagienè, Birutè. 2014; 2015. Vilnius: Lietuvių kalbos institutas.

Šiaurès žemaičiai telšiškiai, 2013: Pabrèža, Juozas; Marcišauskaitè, Vida; Leskauskaite, Asta, sud. Vilnius: Lietuvių kalbos institutas. Taip šneka tirkšliškiai: šiaurès žemaičių telšiškių tarmès tekstai su komentarais, 1996: Girdenis, Aleksas, sud. Vilnius: Mokslo ir enciklopedijų leidykla.

Padalyvinès, pusdalyvinès ir dalyvinès aplinkybès, - Ulvydas Kazys, red., Lietuviu kalbos gramatika 3. Sintaksè. Vilnius: Mokslas, 527-540.

Prijungiamieji sakiniai, - Ulvydas Kazys, red., Lietuvių kalbos gramatika 3. Sintaksé. Vilnius: Mokslas, 789-916. 
Ambrazas, Vytautas. 2006 (1994).

Auwera, Johan van der. 1999.

Cristofaro, Sonia. 2005.

Croft, William. 1990.

Croft, William. 2012.

Girdenis, Aleksas. 1996.

Haiman, John.

1985.

Hengeveld, Kees. 1998.

Holvoet, Axel. 2003.

Huddleston, Rodney H. 1999.

Huddleston, Rodney, Pullum K. Geoffrey, ed. 2002.

Jablonskis, Jonas. [1911]/1957.

Kortmann, Bernd. 1997.

Kortmann, Bernd. 1998.

Langacker, Ronald W. 1991.

Levinson, Stephen C. 2003.
Prijungiamieji sakiniai, - Ambrazas Vytautas (red.), Dabartinès lietuviu kalbos gramatika, Vilnius: Mokslo ir enciklopediju leidybos institutas, 658-696.

Adverbs and adverbials, - Brown Keith, Miller Jim, eds., Concise Encyclopedia of Grammatical Categories, Amsterdam: Elsevier, 8-12.

Subordination. Oxford, New York: Oxford University Press.

Typology and Universals, Cambridge: University Press.

Verbs: Aspect and Causal Structure. Oxford: Oxford University Press.

İvadinès pastabos ir komentarai, - Taip šneka tirkšliškiai: šiaurès žemaičių telšiškių tarmès tekstai su komentarais. Vilnius: Mokslo ir enciklopedijų leidykla.

Natural Syntax. Cambridge: University Press.

Adverbial clauses in the languages of Europe, - Johan van der Auwera, ed., Adverbial Constructions in the Languages of Europe, Berlin, New York: Mouton de Gruyter, 335-420.

Sujungiamieji ir prijungiamieji sakiniai formos bei funkcijos požiūriu, - Holvoet Axel, Judžentis Artūras, red., Sintaksiniu ryšių tyrimai (Lietuvių kalbos gramatikos darbai, 1). Vilnius: Lietuviu kalbos institutas, 99-114.

Sentence types and clause subordination, - Brown Keith, Miller Jim (eds.), Concise Encyclopedia of Grammatical Categories, Amsterdam: Elsevier, 329-343.

The Cambridge Grammar of the English Language. Cambridge: The Press Syndicate of the University of Cambridge.

Lietuvjų kalbos sintaksè, - Jablonskis, Jonas, Rinktiniai raštai 1. Palionis, Jonas, sud. Vilnius: Valstybinè politinès ir mokslinès literatūros leidykla, 435-549.

Adverbial Subordination. A Typology and History of Adverbial Subordinators Based on European Languages. Series: Empirical Approaches to Language Typology [EALT], volume 18, Berlin, New York: Walter de Gruyter.

Adverbial subordinators in the languages of Europe, - Johan van der Auwera, ed., Eurotyp, 3, Adverbial Constructions in the Languages of Europe, Berlin, New York: Mouton de Gruyter, 457-561.

Foundations of Cognitive Grammar, Volume II, Descriptive Application. Stanford, California: Stanford University Press.

Space in Language and Cognition. Cambridge, New York: Cambridge University Press. 
Lubienè, Jūratè, Pakalniškienè, Dalia.

2015.

Nau, Nicole, Ostrowski, Norbert.

2010.

Pabrèža, Juozas.

2013.

Pabrèža, Juozas.

2017.

Pajèdienè, Jūratè.

2012.

Pajèdienè, Jūratè.

2018.

Subačius, Giedrius. 2014.

Traugott, Elizabeth C. 1978.

Vanagienè, Birutè. 2014.

Whaley, Lindsay J. 1997.

Zinkevičius, Zigmas. 1994.
Žemaitiškasis būtasis dažninis laikas: dabarties situacija, Kalbos istorijos ir dialektologijos problemos 3, Vilnius: Lietuviu kalbos institutas, 255-268.

Background and perspectives for the study of particles and connectives in Baltic languages, - Nicole Nau, Norbert Ostrowski (eds.), Particles and Connectives in Baltic, Vilnius: Vilnius University, Asociacija „Academia Salensis“, 1-37.

Skiriamosios šiaurès žemaičiu telšiškių ypatybès, - Šiaurès žemaičiai telšiškiai, 2013: Pabrèža, Juozas; Marcišauskaitè, Vida; Leskauskaitè, Asta, sud. Vilnius: Lietuvių kalbos institutas, 30-39.

Žemaičiu kalba ir rašyba, Šiauliai: Šiaulių universiteto bibliotekos Leidybos skyrius.

Senosios lietuviu kalbos sudètiniai prijungiamieji laiko sakiniai. Humanitarinių mokslų daktaro disertacija, Vilnius: Lietuvių kalbos institutas.

Santykinio laiko raiška prieveiksminiais laiko sakiniais šiaurès žemaičių telšiškių tarmèje, - Baltu filologỉja 27(1/2), 75-100.

Birutès Rokaitès-Vanagienès žodynas ir kiti darbai, - Birutė Vanagienè, sud., Šiaurès vakaru žemaičiu žodynas. Ylakiu, Lenkimu, Mosèdžio, Skuodo, Šačių apylinkių šnektos, A-O, Vilnius: Lietuvių kalbos institutas, XI-XII.

On the expression of spatio-temporal relations in language, Joseph H. Greenberg., Charles A. Ferguson, Edith A. Moravcsik, eds., Universals of Human Language 3, Stanford: Stanford University Press, 369-400.

Pratarmè. İvadinès pastabos, - Birutè Vanagienè, sud., Šiaurès vakaru žemaičiu žodynas: Ylakiu, Lenkimu, Mosèdžio, Skuodo, Šačių apylinkių šnektos, A-O, Vilnius: Lietuvių kalbos institutas, XXIII-XXVIII.

Introduction to Typology: The Unity and Diversity of Language. Newbury Park: Sage.

Lietuviu kalbos dialektologija. Vilnius: Mokslo ir enciklopediju leidykla.

Jūrate Pajedienè

Raštijos paveldo tyrimu centras

Lietuviu kalbos institutas

P. Vileišio 5, LT-10308 Vilnius, Lietuva

juratepajediene@gmail.com 


\title{
KOPSAVILKUMS
}

\section{Saliktie laika teikumi ziemeḷžemaišu izloksnē (20. gadsimta otrās puses mantojumā)}

\author{
Jūratė PAJĖDIENĖ
}

\begin{abstract}
Rakstā aplūkotas vārdnīcas „Šiaurès vakarų žemaičių žodynas, A-O“ (ŠVŽŽ 1) ilustratīvajā materiālā atrodamo salikto laika teikumu strukturālās un morfosintaktiskās iezīmes. Salīdzināšanas nolūkā tika analizēti arī citos ziemel̦žemaišu izloksnes avotos - „Taip šneka tirkšliškiai“ (TŠT) un „Šiaurès žemaičiai telšiškiai“ (ŠŽT) - atrodamie saliktie laika teikumi.

Pētīijumā analizētajos 20. gadsimta otrās puses ziemel̦žemaišu dialekta avotos palīgteikumi ar ka, kad, kaip, kol veido absolūto laika palīgteikumu vairākumu ( 94 \% ŠVŽŽ 1, 95 \% TŠT un 97 \% ŠŽT). Dažiem subordinatoriem ir funkcionāli dublikāti: žemaišu lig var būt subordinators ne tikai palīgteikumos, kas izsaka laika robežu (šì lig funkcija ir raksturīga arī mūsdienu lietuviešu valodai), bet arī palīgteikumos, kas izsaka sekundāru darbību kā atskaites punktu; šādos palīgteikumos vārdi lig un tik var tikt lietoti subordinatora funkcijā, lai gan tos biežāk lieto kā pastiprinājuma partikulas; tujau(s) var izmantot gan kā subordinatoru, gan kā korelējošu vārdu. Tikai ŠVŽŽ 1 atrasti palīgteikumi, kas apzīmē sekundāru darbību kā atskaites punktu, kuros subordinatora funkcijā lietoti vārdi jau, sau, vos (tos parasti izmanto kā pastiprinājuma partikulas vai fāzes adverbus).

Visos trīs avotos salīdzinoši visbiežāk ir sastopami saliktie laika teikumi ar darbības vārdiem vienā un tajā pašā gramatiskajā laikā abās daḷās; tomēr žemaiši mēdz izvēlēties arī dažādu gramatisko laiku formu kombinācijas virsteikumā un palīgteikumā. Attiecībā uz virsteikumu laika palīgteikumi ar vispārējās un mirkḷa nozīmes saistītājvārdiem parasti tiek lietoti prepozicionāli, turpretī laika robežu izteicoši palīgteikumi ir novietoti postpozicionāli. Šāda salikto laika teikumu modeḷu struktūra var būt saistīta ar dialoğismu un dabiskai valodas plūsmai raksturīgāku ikonisku, nevis apgrieztu divu darbību secības attēlojumu.
\end{abstract}

\section{SUMMARY}

\section{Subordinate Clauses of Time in the Northern Samogitian Dialect (Based on the Heritage of the Second Half of the Twentieth Century)}

\author{
Jūratè PAJĖDIENE
}

The article discusses the structural and morphosyntactic features of the subordinate clauses of time recorded in the illustrations of The Dictionary of Northwestern Samogitian, $A-O(\check{S} V Z \check{Z} Z$ 1). For the sake of comparison, temporal clauses found in other sources of the Northern Samogitian dialect - Taip šneka tirkšliškiai $(T S ̌ T)$ and Šiaurés žemaičiai telšiškiai $(\check{S} Z ̌ T)$ - were analysed as well.

In the sources of the Northern Samogitian dialect of the second half of the twentieth century analysed in the study the clauses with ka, kad, kaip, kol constitute an absolute majo-

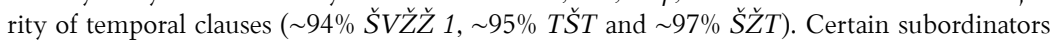
have their functional duplicates: Samogitian lig may serve as a subordinator not only in the clauses referring to a temporal boundary (this function of lig is also characteristic of Modern Lithuanian) but also in clauses referring to a secondary action as the starting point; in clauses 
referring to an action as the starting point the words lig and tik may serve the function of a subordinator, though they are more often used as focus particles; tujau(s) may be used both as

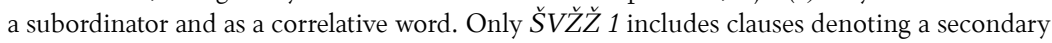
action as the starting point where the function of a subordinator may be assigned to the words jau, sau, vos (they are usually used as focus particles or phase adverbs).

Sentences featuring verbs of the same grammatical tense in both clauses are relatively most common in all three sources; however, Samogitian speakers also tend to choose combinations of different grammatical tense forms in the main clause and the subordinate clause. With respect to the main clause, temporal clauses with connectors of general and momentary meaning are usually used prepositionally, whereas clauses expressing a temporal boundary are placed postpositionally. Such a structure of models of subordinate temporal clauses may be linked to dialogism and iconicity, which is more usual in the natural language flow, rather than the inverse presentation of the sequence of two actions. 